\title{
Monitoring of Brain and Systemic Oxygenation in Neurocritical Care Patients
}

\author{
Mauro Oddo - Julian Bösel · and the Participants in the International \\ Multidisciplinary Consensus Conference on Multimodality Monitoring
}

Published online: 11 September 2014

(c) Springer Science+Business Media New York 2014

\begin{abstract}
Maintenance of adequate oxygenation is a mainstay of intensive care, however, recommendations on the safety, accuracy, and the potential clinical utility of invasive and non-invasive tools to monitor brain and systemic oxygenation in neurocritical care are lacking. A literature search was conducted for English language articles describing bedside brain and systemic oxygen monitoring in neurocritical care patients from 1980 to August 2013. Imaging techniques e.g., PET are not considered. A total of 281 studies were included, the majority described patients with traumatic brain injury (TBI). All tools for oxygen monitoring are safe. Parenchymal brain oxygen $\left(\mathrm{PbtO}_{2}\right)$ monitoring is accurate to detect brain hypoxia, and it is recommended to titrate individual targets of cerebral perfusion pressure (CPP), ventilator parameters $\left(\mathrm{PaCO}_{2}, \mathrm{PaO}_{2}\right)$, and transfusion, and to manage intracranial hypertension, in combination with ICP monitoring. $\mathrm{SjvO}_{2}$ is less accurate than $\mathrm{PbtO}_{2}$. Given limited data, NIRS is not
\end{abstract}

The Participants in the International Multidisciplinary Consensus Conference on Multimodality Monitoring are listed in "Appendix" section

Electronic supplementary material The online version of this article (doi:10.1007/s12028-014-0024-6) contains supplementary material, which is available to authorized users.

\section{Oddo $(\bowtie)$}

Department of Intensive Care Medicine, Faculty of Biology and Medicine, CHUV-Lausanne University Hospital, 1011

Lausanne, Switzerland

e-mail: mauro.oddo@chuv.ch

J. Bösel

Neurocritical Care Section, Department of Neurology,

University of Heidelberg, Heidelberg, Germany recommended at present for adult patients who require neurocritical care. Systemic monitoring of oxygen $\left(\mathrm{PaO}_{2}\right.$, $\left.\mathrm{SaO}_{2}, \mathrm{SpO}_{2}\right)$ and $\mathrm{CO}_{2}\left(\mathrm{PaCO}_{2}\right.$, end-tidal $\left.\mathrm{CO}_{2}\right)$ is recommended in patients who require neurocritical care.

Keywords Brain oxygen - Jugular oxygen saturation . Near-infrared spectroscopy · Carbon dioxide . Systemic oxygenation $\cdot$ Neurocritical care

\section{Introduction}

Maintenance of adequate oxygenation is a primary objective of critical care, and the assessment of tissue oxygenation is essential to patient management. Hypoxia is defined as the reduction of tissue oxygenation to levels insufficient to maintain cellular function and metabolism. Hypoxia may result from ischemia-either macro-vascular (reduced/absent cerebral blood flow [CBF] e.g., vascular thrombosis, vasospasm, reduced carbon dioxide $\left[\mathrm{PaCO}_{2}\right]$ ) or micro-vascular (perivascular edema, blood-brain barrier disruption, endothelial dysfunction) - anemia, and hypoxemia. Cytopathic hypoxia is primarily from failure of the cell to extract oxygen (e.g., oxygen diffusion barriers and/ or mitochondrial dysfunction).

Failure to maintain adequate oxygenation aggravates secondary brain damage, therefore, detection and treatment of brain and systemic hypoxia are important. Hyperoxia also can aggravate outcome. Brain oxygen can be measured by two invasive bedside techniques: brain tissue oxygen tension $\left(\mathrm{PbtO}_{2}\right)$ and jugular bulb oxygen saturation $\left(\mathrm{SjvO}_{2}\right)$; or a non-invasive bedside method: near-infrared spectroscopy (NIRS). Monitoring of systemic oxygenation and $\mathrm{CO}_{2}$ can be achieved invasively with arterial blood gas analysis and noninvasively with pulse oximetry and end-tidal $\mathrm{CO}_{2}$ devices. 
The objective of this systematic review was to (1) examine the safety and accuracy of systemic and brain oxygen and $\mathrm{CO}_{2}$ monitoring; (2) evaluate its utility to guide therapy; and (3) analyze whether oxygen or $\mathrm{CO}_{2}$ monitoring-guided therapy improves patient outcome after acute brain injury (ABI) including traumatic brain injury (TBI), subarachnoid hemorrhage (SAH), intracerebral hemorrhage (ICH), acute ischemic stroke (AIS), or postcardiac arrest (CA) coma.

\section{Methods}

This systematic review was performed according to the Preferred Reporting Items for Systematic Reviews and Meta-Analyses (PRISMA) statement [1].

\section{Search Criteria}

Studies were considered eligible based on the PICO approach, which includes: (a) Patient population, i.e., critically ill TBI, SAH, ICH, AIS, or comatose CA patients; (b) Intervention provided, i.e., $\mathrm{PbtO}_{2}, \mathrm{SjvO}_{2}$, NIRS for regional cerebral oxygen saturation $\left(\mathrm{rSO}_{2}\right)$, arterial blood gas analysis (ABG) monitoring of arterial oxygen saturation $\left(\mathrm{SaO}_{2}\right)$ /partial arterial oxygen pressure $\left(\mathrm{PaO}_{2}\right)$ /partial arterial carbon dioxide pressure $\left(\mathrm{PaCO}_{2}\right)$, pulse oximetry $\left(\mathrm{SpO}_{2}\right)$, capnometry for partial end-tidal pressure of carbon dioxide $\left(\mathrm{ETCO}_{2}\right)$; (c) Controls, i.e., ABI patients without monitoring or patients without ABI who underwent monitoring, or ABI patients monitored with more than one device or in whom correlations with relevant variables were analyzed; (d) Outcome endpoints, i.e., mortality, Glasgow Outcome Score (GOS), Glasgow Coma Scale (GCS), modified Rankin Scale (mRS), functional independence scores, neurological outcome, National Institute of Health Stroke Scale, intensive care unit (ICU), and hospital length of stay, duration of mechanical ventilation, complications, therapy modification, and changes in physiological variables. Imaging techniques are not part of this review. After selection, the evidence was classified and practical recommendations were developed according to the Grades of Recommendation, Assessment, Development, and Evaluation (GRADE) system [2, 3].

Using the PubMed database, a systematic review was performed (1980-August 2013) of the English language literature. We did not consider unpublished data or congress presentations/abstracts. The search strategy included the terms: brain injury, traumatic brain injury (and related terms: head trauma, neurotrauma, head injury), subarachnoid hemorrhage, intracerebral hemorrhage, acute ischemic stroke, large hemispheric infarction, malignant middle cerebral artery infarction, cardiac arrest, hypoxic encephalopathy, brain oxygen, brain tissue oxygen, brain tissue oxygen pressure, brain tissue oxygen tension, brain oxygenation, brain tissue oxygenation, near-infrared spectroscopy, cerebral oximetry, cerebral oxygenation, cerebral tissue oxygenation, jugular bulb saturation, jugular venous bulb oxygen saturation, jugular venous oxygen saturation, jugular oximetry, systemic oxygenation, arterial oxygen saturation, pulse oximetry, oximetry, central venous oxygenation, arterio-venous oxygen saturation difference, partial arterial oxygen pressure, partial arterial carbon dioxide pressure, blood gas analysis, ischemia, secondary ischemia, brain hypoxia, brain tissue hypoxia, hypoxia, cerebral ischemia, brain ischemia, delayed cerebral ischemia, vasospasm, cerebral perfusion imaging, mean arterial pressure, intracranial pressure, cerebral perfusion pressure, cerebral blood flow, hemoglobin, hematocrit, anemia, transfusion, positive end expiratory pressure, fraction of inspired oxygen, hypoxemia, mortality, Glasgow Outcome Score, Glasgow Coma Scale, modified Rankin Scale, functional independence scores, neurological outcome, National Institute of Health Stroke Scale, Intensive Care Unit length of stay, duration of ventilation, hospital length of stay, discharge to home, discharge to institutional care, and prognosis.

\section{Study Selection and Data Collection}

Articles were independently pre-selected according to their title to identify those describing invasive brain oxygen, non-invasive brain oxygen, and systemic oxygen monitoring. We excluded: (a) review articles; (b) case reports or case series with $\leq 5$ patients; (c) animal studies; (d) pediatric studies ( $<18$ years); (e) studies that were not conducted on ICU patients; and (f) studies performed on patients without our pre-defined diseases.

\section{Review Endpoints}

The endpoints of this review were to answer the following broad questions on oxygen monitoring: (1) is monitoring safe and accurate, (2) does monitoring help guide management, and (3) does monitoring help to improve outcome? Specific questions that were addressed include:

1. What are the indications for brain and systemic oxygenation in neurocritical care patients?

2. What are the principal methods of reliable and accurate brain oxygen monitoring?

3. What is the safety profile of brain oxygen monitoring?

4. What is the utility of brain oxygen monitoring to determine prognosis in the comatose patient?

5. What is the utility of brain oxygen monitoring to direct medical and surgical therapy? 
6. What is the utility of brain oxygen monitoring to improve neurological outcome?

\section{Grading of Evidence}

The quality of available evidence was judged based on the GRADE system. Summaries of the literature are followed by recommendations. Additional findings and conclusions are given in an on-line supplementary tables.

\section{Results}

Summary of the Literature

The initial search yielded 7,762 articles and abstracts and 529 articles were reviewed. After exclusions, the reviewers identified 281 articles for inclusion; 161 for $\mathrm{PbtO}_{2}, 57$ on $\mathrm{SjvO}_{2}, 29$ on NIRS, and 34 on systemic oxygenation monitoring. More than two-thirds of the articles described TBI patients. We found 3 randomized controlled trials (RCT) for $\mathrm{PbtO}_{2}$ monitoring, 1 for $\mathrm{SjvO}_{2}$ monitoring, 1 for NIRS monitoring, and 3 for systemic oxygen monitoring. All other studies were non-RCT (case-controlled studies, prospective/observational, retrospective studies). A large majority were retrospective studies. The structure of this chapter is separated into four main parts: (1) $\mathrm{PbtO}_{2}$, (2) $\mathrm{SjvO}_{2}$, (3) NIRS, (4) ABG and $\mathrm{ETCO}_{2}$.

\section{$\mathrm{PbtO}_{2}$ Monitoring}

Regional brain tissue oxygen tension $\left(\mathrm{PbtO}_{2}\right)$ monitoring requires insertion of a catheter into the brain parenchyma (sub-cortical white matter), through a single or multiple lumen bolt or tunneled. Generally patients are selected for $\mathrm{PbtO}_{2}$ monitoring when intracranial pressure (ICP) is monitored.

\section{Is $\mathrm{PbtO}_{2}$ Monitoring Safe and Accurate?}

Eight studies tested safety and accuracy [4-11]: in summary, they found no catheter-related infections, 0-3\% local bleeding around the catheter (with no clinical consequence), 6-14\% technical complications (e.g., dislocation or defect). Catheters are MRI 1.5 Tesla compatible. For data accuracy, adaptation time was $\sim 2 \mathrm{~h}$, display error $\sim 2-3 \mathrm{mmHg}$, zero-drift $\sim 2 \mathrm{mmHg}$ : display errors and drift were greater during the first 4 days of monitoring.

The Licox ${ }^{\circledR}$ system from Integra Neurosciences and the Neurovent-PTO ${ }^{\circledR}$ system from Raumedic are currently commercially available, and provide stable monitoring for up to 7-10 days. In comparative studies, there are differences in absolute $\mathrm{PbtO}_{2}$ values, $\mathrm{PbtO}_{2}$ response to $\mathrm{FiO}_{2}$ increase, and $\mathrm{PbtO}_{2}$-derived indexes between the two devices [12-16]. Fever $\left(\sim 39{ }^{\circ} \mathrm{C}\right)$ may affect the Licox data.

$\mathrm{CBF}$ and CPP are important determinants of $\mathrm{PbtO}_{2}[17-$ 30], but a $\mathrm{PbtO}_{2}$ monitor is not simply an "ischemia monitor" since several variables such as $\mathrm{PaCO}_{2}$ [31-40], $\mathrm{PaO}_{2}[23,41,42]$, systemic factors that modify $\mathrm{CMRO}_{2}$ (e.g., fever, shivering [43, 44]) alter $\mathrm{PbtO}_{2} . \mathrm{PbtO}_{2}$ best reflects the product of $\mathrm{CBF}$ and arterio-venous oxygen tension difference [23] and is influenced by the oxygen diffusion gradient [45]. Hence, when local tissue extraction of $\mathrm{O}_{2}$ is impaired (e.g., peri-vascular edema), $\mathrm{PbtO}_{2}$ may be low despite normal $\mathrm{CBF}$.

"Normal" $\mathrm{PbtO}_{2}$ is $23-35 \mathrm{mmHg}[5,46,47]$ but depends on probe depth, being less in deeper brain regions [5]. Values $<20 \mathrm{mmHg}$ are considered abnormal and have been associated with greater evidence for cerebral ischemia and energy dysfunction [48-50]. In many centers, treatment is initiated when $\mathrm{PbtO}_{2}$ is $<20 \mathrm{mmHg}$ although other authors describe treatment when $\mathrm{PbtO}_{2}$ is $<15 \mathrm{mmHg}$ [51].

Probe location can influence how $\mathrm{PbtO}_{2}$ responds to therapeutic interventions and its association with outcome in TBI [52-56]. In general, $\mathrm{PbtO}_{2}$ absolute values and the response of $\mathrm{PbtO}_{2}$ to $\mathrm{FiO}_{2}$ are less in peri-contusional areas compared to normal brain visualized on CT scan [52-54, 56]. In $\mathrm{SAH}$, the ability of a $\mathrm{PbtO}_{2}$ probe to detect ischemia associated with vasospasm depends on probe placement and is better when the MCA or ICA is involved [57]. It is important, therefore, that $\mathrm{PbtO}_{2}$ data be interpreted once a post-insertion CT scan has verified probe position.

\section{Does $\mathrm{PbtO}_{2}$ Monitoring Help Guide Management?}

Most studies include comatose TBI patients and less frequently $\mathrm{SAH}$ patients. $\mathrm{PbtO}_{2}$ monitoring can guide several aspects of patient care. $\mathrm{PbtO}_{2}$ monitoring helps target "optimal CPP levels" (i.e., a CPP level to prevent/treat brain tissue hypoxia, $\left.\left[\mathrm{PbtO}_{2}<20 \mathrm{mmHg}\right]\right)$ in individual patients or a level at which ICP requires treatment in TBI [22, 29, 58-62] and $\mathrm{SAH}[30,63,64] . \mathrm{PbtO}_{2}$ data can be used to identify deleterious effects of drugs on CPP [6567] and document the effect of interventions such as induced hypertension to increase CPP [20, 68-70]. Patient's autoregulation state can be identified using the online correlation between CPP and $\mathrm{PbtO}_{2}$, or the oxygen pressure reactivity index (ORx), which helps target CPP in TBI [18, 21, 71-73], SAH [27, 74], and stroke [26]. The effect of osmotherapy to control ICP can be guided by $\mathrm{PbtO}_{2}$ data [75-78]. Other ICP therapies (hypothermia [7983], barbiturates [84, 85], or decompressive craniectomy [86-88]) can be guided by $\mathrm{PbtO}_{2}$ data. In patients receiving 
hypothermia $\mathrm{PbtO}_{2}$ monitors may detect deleterious effects associated with a change in $\mathrm{CO}_{2}$ affinity or with shivering $[43,83,89,90]$. Anemia (hemoglobin $<9 \mathrm{~g} / \mathrm{dl}$ ) is associated with lower $\mathrm{PbtO}_{2}$ after TBI [91] and SAH [92, 93] and $\mathrm{PbtO}_{2}$ monitoring may help guide transfusion endpoints [91, 94-97]. The variable effects of sedation, anesthetic agents, and "wake-up tests" on individual patients can be examined using $\mathrm{PbtO}_{2}$ data [98-105]. $\mathrm{PbtO}_{2}$ levels may help guide ventilator management [106]. There is a well-described relationship between hyperventilation, reduced $\mathrm{PaCO}_{2}$, and decreased $\mathrm{PbtO}_{2}$ as well as between impaired lung function and low $\mathrm{PbtO}_{2}$ : recruitment maneuvers (PEEP of 30-40 $\mathrm{cmH} 2 \mathrm{O}$ ) may thus help improve $\mathrm{PbtO}_{2}$ [107] but this effect may depend on hemodynamic stability [108]. Finally $\mathrm{PbtO}_{2}$ monitor use and changes in ORx are described in SAH induced vasospasm management [27, 74, 109-117] both to provide insight about an intervention or to "predict" delayed cerebral ischemia $[109,110,114]$.

\section{Does $\mathrm{PbtO}_{2}$-Guided Care Influence Outcome?}

Twenty-four studies (21 TBI, $3 \mathrm{SAH}$ ) describe an association between reduced $\mathrm{PbtO}_{2}$ (using thresholds of $<20,<15$ and $<10 \mathrm{mmHg}$ ) and worse outcome. In TBI, reduced $\mathrm{PbtO}_{2}$ is associated with mortality [118-123], lower GOS score [124130], and increased neuropsychological deficits [131]. $\mathrm{PbtO}_{2}$ values of $0 \mathrm{mmHg}$ are consistent with brain death $[132,133]$. The tissue oxygen response (TOR; i.e. $\mathrm{PbtO}_{2}$ response to $100 \% \mathrm{FiO}_{2}$ ) also is associated with TBI outcome [134-136]. In $\mathrm{SAH}$ there is a relationship between reduced $\mathrm{PbtO}_{2}$ and mortality but the relationship with morbidity is less robust than in TBI [114, 137, 138].

Interventions such as ventilator manipulation (e.g. a change in $\mathrm{FiO}_{2}$ or PEEP), CPP augmentation, sedation, or osmotherapy are most frequently used to treat low $\mathrm{PbtO}_{2}$. Overall medical therapy can correct three quarters of the episodes of compromised $\mathrm{PbtO}_{2}(<20 \mathrm{mmHg})$ but varies with the specific therapy or combination of therapies [139, 140]. Increased $\mathrm{FiO}_{2}$ generally is the most effective therapy and both normobaric and hyperbaric oxygen can increase $\mathrm{PbtO}_{2}$, although the exact response may depend on probe position [52, 141-149]. Whether this translates into improved cerebral metabolism and better tissue outcome is still controversial.

A physiologic response to therapy to correct $\mathrm{PbtO}_{2}$ is associated with better outcomes in TBI and SAH [139, 150]. Nine observational studies have described the effect of $\mathrm{PbtO}_{2}$-directed therapy used with ICP/CPP management in severe TBI [151-159], suggesting a tendency to better outcomes with combined $\mathrm{PbtO}_{2}$ and ICP/CPP therapy compared to ICP/CPP therapy alone in the majority of them.
$\mathrm{SjvO}_{2}$ Monitoring

Jugular bulb catheters sample the intracranial circulation. Measuring jugular bulb venous oxygen saturation $\left(\mathrm{SjvO}_{2}\right)$ or the difference between arterial and jugular venous oxygen content $\left(\mathrm{AJVDO}_{2}\right)$ provides information about global cerebral oxygenation. The catheter should be in the dominant internal jugular vein and proximal to the first extra-cranial tributary, the facial vein for best results [160163]. A cervical spine x-ray is recommended to define correct position [164].

\section{Is $\mathrm{SjvO}_{2}$ Monitoring Safe and Accurate?}

Jugular bulb blood can be sampled intermittently with a catheter or continuously using a fiberoptic catheter. Catheters need frequent calibration usually every $8-12 \mathrm{~h}[165$, 166]. Poor quality signals from extra-cranial contamination associated with inaccurate placement, clot formation, catheter, and venous thrombosis or inadequate calibration are common [167-171]. Hence data accuracy ranges between 40 and $80 \%$ [171-173] of total monitored time. Several studies have compared $\mathrm{SvjO}_{2}$ and $\mathrm{PbtO}_{2}$ monitoring [172, 174-179]. Overall these studies show $\mathrm{SjvO}_{2}$ is less accurate than $\mathrm{PbtO}_{2}$.

Normal $\mathrm{SjvO}_{2}$ is between 55 and $75 \%$. Although various definitions have been used, $\mathrm{SjvO}_{2}$ values $<55 \%$ are consistent with cerebral ischemia [180-185]. At least $13 \%$ of the brain volume needs to be ischemic for the $\mathrm{SjvO}_{2}$ to be abnormal and so its ability to detect regional ischemia is limited [186-191].

\section{Can SjvO $\mathrm{O}_{2}$ Monitoring Help Guide Management?}

The majority of studies have been in TBI patients, with only few data in SAH or AIS. Reduced CPP is a common cause of $\mathrm{SjvO}_{2}$ desaturation [192-198] and optimization of CPP can reduce these episodes of low $\mathrm{SjvO}_{2}$ [196, 197, 199, 200]. Increased ICP also is associated with reduced $\mathrm{SjvO}_{2}[192,201,202]$ but the response of $\mathrm{SjvO}_{2}$ to ICP treatment including hyperventilation, osmotherapy, surgery, or hypothermia is variable [202-206]. A decrease in $\mathrm{SjvO}_{2}$ associated with hyperventilation can be used to deescalate therapy i.e., guide hyperventilation during ICP treatment [195, 196, 207-212]. A failure of $\mathrm{AVDO}_{2}$ to improve once ICP is normalized is associated with a greater likelihood of cerebral infarction [213]. Sedatives such as propofol or opiates have an uncertain effect on $\mathrm{SjvO}_{2}[103,214,215]$. There are limited studies in $\mathrm{SAH}$ but they suggest changes in $\mathrm{SjvO}_{2}$ or $\mathrm{AVDO}_{2}$ may precede neurologic symptoms associated with vasospasm and so can be used to titrate or institute induced hypervolemia or hypertension [196, 216]. 
Does $\mathrm{SjvO}_{2}$-Guided Care Influence Outcome?

In TBI patients, reduced $\mathrm{SjvO}_{2}$ [180-182, 184, 203, 217], increased $\mathrm{SjvO}_{2}(>75 \%)$ [180], and increased $\mathrm{AVDO}_{2}$ $[185,213,218]$ are associated with worse outcome. An $\mathrm{SjvO}_{2}<50 \%$ for more than $10 \mathrm{~min}$ or failure of the $\mathrm{AVDO}_{2}$ to respond to treatment are associated with worse outcome [182, 213].

In a randomized controlled study, Robertson et al. [200] examined whether a CBF-targeted protocol, using higher CPP and optimized volume management but without targeting a specific range $\mathrm{SjvO}_{2}$ improved outcome compared to standard ICP-based care in severe TBI. Patients assigned to the CBF-targeted management had fewer episodes with low $\mathrm{SjvO}_{2}<55 \%$ but 6-month outcome was similar because of a greater incidence of pulmonary complications in the CBF-targeted protocol group.

\section{Near-Infrared Spectroscopy (NIRS)}

Near-infrared spectroscopy (NIRS) is based on the principle that light (wavelength $700-950 \mathrm{~nm}$ ) passing through biological tissue is absorbed by blood depending on its oxygenation status. The attenuation of light allows estimation of oxygen status in the tissue volume reached by the light. While NIRS use is better described in cardiothoracic surgery and in neonatal or pediatric critical care, we only reviewed studies in adult neurocritical care in which commercially available devices were used. Most of these studies are small, there are several methodological limitations, and results are conflicting. Furthermore, NIRS has several limitations in adult use [219-223].

Currently, four commercial NIRS systems are available: (1) FORE-SIGHT (CAS Medical Systems, Branford, Connecticut, USA; FDA-approved); (2) EQUANOX (Nonin Medical, Plymouth, Minnesota, USA; FDA-approved); (3) INVOS (Covidien, Boulder, Connecticut, USA; FDAapproved); and (4) NIRO (Hamamatsu Photonics, Hamamatsu City, Japan; CE-marked). The INVOS and the NIRO are the most widespread in clinical use. There is insufficient data to recommend one device over the other. For intermonitor comparisons and technical aspects, the reader is referred elsewhere [220, 223-237].

\section{Is NIRS Monitoring Safe and Accurate?}

While only two studies specifically addressed safety and the application of NIRS [219, 238], no adverse effects were described in other studies. Seventeen studies examined how NIRS compared to other measures of brain oxygen and perfusion including changes in these variables. The results are very variable with good [222, 239-249], partial [219,
222, 238, 240-250], or poor correlation [251-254]. In large part, this variability results from factors such as ambient light, scalp, skull, and CSF conditions [223] or extra-cranial circulation that influence the NIRS signal [220, 224].

\section{Can NIRS Monitoring Help Guide Management?}

Nineteen studies, mostly small observational studies, describe how NIRS may be used to understand patient physiology or guide management in neurocritical care. This includes use in ICP waveform analysis [255]; cerebral autoregulation [248, 249, 256]; CPP and MAP assessment [60, 222, 251, 257-260]; vasospasm [221, 261, 262]; head positioning [263], hematoma assessment, and surgical decision making [264-266]. The results are mixed.

\section{Does NIRS Monitoring Help to Improve Outcome?}

There are very limited data on this question and no studies to show that NIRS use helps to improve outcome in adult neurocritical patients. Ideally, NIRS should be used with other monitors and most studies suggest it is easy to incorporate NIRS into multimodal monitoring. This is best exemplified in its use to assess cerebral autoregulation [248, 249].

\section{NIRS: Conclusions}

While NIRS is an attractive monitor since it is non-invasive, it has several limitations in adult use and at present has little if any role in adult neurocritical care. In particular, NIRS, alone, is currently not indicated for routine monitoring of adult patients who require neurocritical care. Instead if NIRS is to be used, it is best integrated with other monitors to answer research questions but at the moment not to guide management.

\section{Systemic Oxygen Monitoring}

Systemic oxygen can be measured invasively by arterial blood gas analysis (ABG) for $\mathrm{PaO}_{2}$ and $\mathrm{SaO}_{2}$ and noninvasively with pulse oximetry (for $\mathrm{SpO}_{2}$ ). There are a variety of devices to assess systemic oxygenation but too few technology validation studies in neurocritical care patients to allow recommendation of one device over the other. Most data are from TBI and SAH, thus limiting generalizability. Most studies are small, non-controlled, and suffer methodological weaknesses. Furthermore, systemic oxygen monitoring usually is not the primary endpoint but reported as part of the methods or as a secondary endpoint. Consequently, many studies were not designed to answer the review questions directly and instead provide indirect evidence only. 


\section{Is Systemic Oxygen Monitoring Safe and Accurate?}

No studies specifically address this question in neurocritical care patients, although these devices are used in virtually all these patients. Pulse oximetry has been validated in healthy volunteers [267]. $\mathrm{ABG}$ and $\mathrm{SpO}_{2}$ use are well studied in the operating room and the general ICU where their use is safe and associated with fewer episodes of hypoxia. The impact on outcome is less certain. There is no plausible reason to assume that safety, applicability, methodological reliability, or accuracy would be any different in neurocritical care patients although limited precision has been identified in select circumstances [268270].

\section{Can Systemic Oxygen Monitoring Help Guide Management?}

Systemic hypoxia and hyperoxia are known to exacerbate outcome. Ten studies, including two small RCTs, addressed how systemic oxygen monitoring can guide neurocritical care management. In summary, pulse oximetry or ABG analysis can reliably detect pulmonary and circulatory abnormalities [271], and guide correction of brain oxygen in select patients when using normobaric hyperoxia [147, 272], PEEP [105, 107, 108, 273], recruitment maneuvers [274, 275], or prone positioning [276].

\section{Does Systemic Oxygen Monitoring Help to Improve Outcome?}

There are no outcome studies in neurocritical care that compare patients managed with or without systemic oxygen monitoring. However, two small observational studies and one large retrospective registry provide indirect evidence for the value of systemic oxygen monitoring in TBI. In particular, desaturation on pulse oximetry or both low and very high $\mathrm{PaO}_{2}$ are associated with worse outcome [277-279]. Since cost and risk of systemic oxygen monitoring are low and the value in understanding patient pathophysiology is high, there is no reason not to use systemic oxygen monitoring as part of multimodal monitoring.

\section{Systemic Carbon Dioxide Monitoring}

Systemic carbon dioxide is assessed invasively by arterial blood gas analysis for $\mathrm{PaCO}_{2}$ and non-invasively with capnography, capnometry, and continuous assessment of end-tidal $\mathrm{CO}_{2}\left(\mathrm{ETCO}_{2}\right)$. There are several devices to assess systemic carbon dioxide but too few technology validation studies in neurocritical care to allow recommending one device over the other. The reader is referred elsewhere for details on technology [280-283].The vast majority of studies on carbon dioxide monitoring are in TBI or SAH and usually $\mathrm{CO}_{2}$ is not a primary endpoint, i.e., most evidence is indirect.

\section{Is Systemic Carbon Dioxide Monitoring Safe and Accurate?}

There is extensive research on $\mathrm{CO}_{2}$ analysis using $\mathrm{ABG}$ or $\mathrm{ETCO}_{2}$ monitoring in general critical care and in anesthesia that demonstrate feasibility and safety. These questions have not been specifically addressed in neurocritical care but there is no reason to expect a difference.

ABG-analysis of $\mathrm{PaCO}_{2}$ is routine and in widespread use in all ICUs. Similarly, $\mathrm{ETCO}_{2}$ is used routinely in the operating room [284]. End-tidal $\mathrm{CO}_{2}$ correlates with $\mathrm{PaCO}_{2}$ in healthy ventilated patients but with impaired pulmonary gas exchange (e.g., increased anatomic or physiologic dead space, or low cardiac output) there can be a gradient between $\mathrm{ETCO}_{2}$ and $\mathrm{PaCO}_{2}$ that may change over time [257]. Hence $\mathrm{ETCO}_{2}$ is not a one-for-one substitute for $\mathrm{PaCO}_{2}$ and when $\mathrm{ETCO}_{2}$ is used it should be validated against $\mathrm{PaCO}_{2}$.

\section{Does Systemic Carbon Dioxide Monitoring Help Guide Management?}

Fifteen studies address this question; most are prospective observational studies or case series and use $\mathrm{ETCO}_{2}$ or $\mathrm{PaCO}_{2}$ monitoring [31, 186, 203, 285-292]. $\mathrm{PaCO}_{2}$ monitoring and less reliably $\mathrm{ETCO}_{2}$ can help to detect and guide hyperventilation. There is a reasonable relationship with CBF and brain oxygen but less robust relationship with $\mathrm{CMRO}_{2}$ and oligemia.

\section{Does Systemic Carbon Dioxide Monitoring Help to Improve Outcome?}

There are no outcome studies in neurocritical care that compare patients managed with or without systemic $\mathrm{CO}_{2}$ monitoring. Six studies, including one RCT provide indirect evidence in that they show hyper- or, more often, hypocapnia, to be associated with worse outcome or mortality in TBI [279, 281, 293-295] and SAH [296]. Similar to oxygen monitoring, it makes physiologic sense that $\mathrm{CO}_{2}$ monitoring be incorporated into multimodal monitoring.

Disclosures Mauro Oddo has received speaker and consultant honoraria from Integra Neurosciences. Julian Bösel has received speaker honoraria and travel support from Covidien, Sedana Medical, and Orion Pharma. 
Appendix: Participants in the International Multidisciplinary Consensus Conference on Multimodality Monitoring

Peter Le Roux, MD, FACS,

Brain and Spine Center,

Suite 370, Medical Science Building,

Lankenau Medical Center,

100 East Lancaster Avenue, Wynnewood, PA 19096, USA.

Tel: +1 610642 3005;

Fax: 6106423057

lerouxp@mlhs.org

David K Menon MD PhD FRCP FRCA FFICM FMedSci Head, Division of Anaesthesia, University of Cambridge Consultant, Neurosciences Critical Care Unit

Box 93, Addenbrooke's Hospital,

Cambridge CB2 2QQ, UK

dkm13@wbic.cam.ac.uk

Paul Vespa, MD, FCCM, FAAN, FNCS

Professor of Neurology and Neurosurgery

Director of Neurocritical Care

David Geffen School of Medicine at UCLA

Los Angeles, CA 90095 USA

PVespa@mednet.ucla.edu

Giuseppe Citerio, MD

Director NeuroIntensive Care Unit,

Department of Anesthesia and Critical Care

Ospedale San Gerardo, Monza.

Via Pergolesi 33, Monza 20900, Italy

g.citerio@hsgerardo.org

Mary Kay Bader RN, MSN, CCNS, FAHA, FNCS

Neuro/Critical Care CNS

Mission Hospital

Mission Viejo CA 92691, USA

Marykay.Bader@stjoe.org

Gretchen M. Brophy, PharmD, BCPS, FCCP, FCCM

Professor of Pharmacotherapy \& Outcomes

Science and Neurosurgery

Virginia Commonwealth University

Medical College of Virginia Campus

410 N. 12th Street

Richmond, Virginia 23298-0533 USA

gbrophy@vcu.edu

Michael N. Diringer, MD

Professor of Neurology, Neurosurgery \& Anesthesiology

Chief, Neurocritical Care Section

Washington University
Dept. of Neurology, Campus Box 8111

660 S Euclid Ave

St Louis, MO 63110 USA

diringerm@neuro.wustl.edu

Nino Stocchetti, MD

Professor of Anesthesia and Intensive Care

Department of physiopathology and transplant,

Milan University

Director Neuro ICU

Fondazione IRCCS Cà Granda Ospedale Maggiore

Policlinico

Via F Sforza, 3520122 Milan Italy

e-mail stocchet@policlinico.mi.it

Walter Videtta, MD

ICU Neurocritical Care

Hospital Nacional 'Prof. a. Posadas'

El Palomar - Pcia. de Buenos Aires

Argentina

wvidetta@ar.inter.net

Rocco Armonda, MD

Department of Neurosurgery

MedStar Georgetown University Hospital

Medstar Health, 3800 Reservoir Road NW

Washington DC 20007

USA

Rocco.Armonda@gmail.com

Neeraj Badjatia, MD

Department of Neurology

University of Maryland Medical Center,

22 S Greene St

Baltimore, MD, 21201

USA

nbadjatia@umm.edu

Julian Boesel, MD

Department of Neurology

Ruprect-Karls University

Hospital Heidelberg, Im Neuenheimer Feld 400,

D-69120 Heidelberg,

Germany

Julian.Boesel@med.uni-heidelberg.de

Randal Chesnut, MD, FCCM, FACS

Harborview Medical Center,

University of Washington Mailstop 359766

325 Ninth Ave,

Seattle WA 98104-2499

USA

chesnutr@u.washington.edu 
Sherry Chou, MD, MMSc

Department of Neurology,

Brigham and Women's Hospital

75 Francis Street,

Boston MA 02115

USA

schou1@partners.org

Jan Claassen, MD, PhD, FNCS

Assistant Professor of Neurology and Neurosurgery

Head of Neurocritical Care and Medical Director

of the Neurological Intensive Care Unit

Columbia University College of Physicians \& Surgeons

177 Fort Washington Avenue, Milstein 8 Center room 300,

New York, NY 10032

USA

jc1439@cumc.columbia.edu

Marek Czosnyka, $\mathrm{PhD}$

Department of Neurosurgery

University of Cambridge,

Addenbrooke's Hospital, Box 167

Cambridge, CB20QQ

United Kingdom

mc141@medschl.cam.ac.uk

Michael De Georgia, MD

Professor of Neurology

Director, Neurocritical Care Center

Co-Director, Cerebrovascular Center

University Hospital Case Medical Center

Case Western Reserve University School of Medicine

11100 Euclid Avenue

Cleveland, Ohio 44106

michael.degeorgia@uhhospitals.org

Anthony Figaji, MD, PhD

Head of Pediatric Neurosurgery

University of Cape Town

617 Institute for Child Health

Red Cross Children's Hospital

Rondebosch, 7700 Cape Town,

South Africa

anthony.figaji@uct.ac.za

Jennifer Fugate, DO

Department of Neurology,

Mayo Clinic,

200 First Street SW

Rochester, MN 55905

Fugate.Jennifer@mayo.edu
Raimund Helbok, MD

Department of Neurology, Neurocritical Care Unit

Innsbruck Medical University,

Anichstr.35, 6020

Innsbruck,

Austria

raimund.helbok@uki.at

David Horowitz, MD

Associate Chief Medical Officer

University of Pennsylvania Health System,

3701 Market Street

Philadelphia, PA, 19104

USA

david.horowitz@uphs.upenn.edu

Peter Hutchinson, MD

Professor of Neurosurgery

NIHR Research Professor

Department of Clinical Neurosciences

University of Cambridge

Box 167 Addenbrooke's Hospital

Cambridge CB2 2QQ

United Kingdom

pjah2@cam.ac.uk

Monisha Kumar, MD

Department of Neurology

Perelman School of Medicine, University of

Pennsylvania,

3 West Gates

3400 Spruce Street

Philadelphia, PA, 19104

USA

monisha.kumar@uphs.upenn.edu

Molly McNett, RN, PhD

Director, Nursing Research

The MetroHealth System

2500 MetroHealth Drive,

Cleveland, OH 44109

USA

mmcnett@metrohealth.org

Chad Miller, MD

Division of Cerebrovascular Diseases and

Neurocritical Care

The Ohio State University

395 W. 12th Ave, 7th Floor

Columbus, OH 43210

ChadM.Miller@osumc.edu 
Andrew Naidech, MD, MSPH

Department of Neurology

Northwestern University Feinberg SOM 710

N Lake Shore Drive, 11th floor

Chicago, IL 60611

ANaidech@nmff.org

Mauro Oddo, MD

Department of Intensive Care Medicine

CHUV University Hospital, BH 08-623

Faculty of Biology and Medicine University of Lausanne

Rue de du Bugnon 46

1011 Lausanne

Switzerland

Mauro.Oddo@chuv.ch

DaiWai Olson, RN, PhD

Associate Professor of Neurology, Neurotherapeutics and

Neurosurgery

University of Texas Southwestern

5323 Harry Hines Blvd.

Dallas, TX 75390-8897

USA

daiwai.olson@utsouthwestern.edu

Kristine O'Phelan M.D.

Director of Neurocritical Care

Associate Professor, Department of Neurology

University of Miami, Miller School of Medicine

JMH, 1611 NW 12th Ave, Suite 405

Miami, FL, 33136

USA

kophelan@med.miami.edu

Javier Provencio, MD

Associate Professor of Medicine

Cerebrovascular Center and Neuroinflammation

Research Center

Lerner College of Medicine

Cleveland Clinic,

9500 Euclid Ave, NC30

Cleveland, $\mathrm{OH} 44195$

USA

provenj@ccf.org

Corina Puppo, MD

Assistant Professor, Intensive Care Unit,

Hospital de Clinicas, Universidad de la República,

Montevideo

Uruguay

coripuppo@gmail.com

Richard Riker, MD

Critical Care Medicine
Maine Medical Center,

22 Bramhall Street

Portland, Maine 04102-3175

USA

RRiker@cmamaine.com

Claudia Robertson, MD

Department of Neurosurgery

Medical Director of Center for Neurosurgical Intensive

Care,

Ben Taub Hospital

Baylor College of Medicine,

1504 Taub Loop, Houston, TX 77030

USA

claudiar@bcm.tmc.edu

J. Michael Schmidt, PhD, MSc

Director of Neuro-ICU Monitoring and Informatics

Columbia University College of Physicians and Surgeons

Milstein Hospital 8 Garden South, Suite 331

177 Fort Washington Avenue,

New York, NY 10032

USA

mjs2134@columbia.edu

Fabio Taccone, MD

Department of Intensive Care, Laboratoire de Recherche

Experimentale

Erasme Hospital,

Route de Lennik, 808

1070 Brussels

Belgium

ftaccone@ulb.ac.be

\section{References}

1. Liberati A, Altman DG, Tetzlaff J, et al. The PRISMA statement for reporting systematic reviews and meta-analyses of studies that evaluate healthcare interventions: explanation and elaboration. BMJ. 2009;339:b2700.

2. Schunemann HJ, Oxman AD, Brozek J, et al. GRADE: assessing the quality of evidence for diagnostic recommendations. Evid Based Med. 2008;13:162-3.

3. Schunemann HJ, Oxman AD, Brozek J, et al. Grading quality of evidence and strength of recommendations for diagnostic tests and strategies. BMJ. 2008;336:1106-10.

4. Charbel FT, Hoffman WE, Misra M, Hannigan K, Ausman JI. Cerebral interstitial tissue oxygen tension, $\mathrm{pH}, \mathrm{HCO}_{3}, \mathrm{CO}_{2}$. Surg Neurol. 1997;48:414-7.

5. Dings J, Meixensberger J, Jager A, Roosen K. Clinical experience with 118 brain tissue oxygen partial pressure catheter probes. Neurosurgery. 1998;43:1082-95.

6. Dings J, Meixensberger J, Roosen K. Brain tissue $\mathrm{pO}_{2}$-monitoring: catheterstability and complications. Neurol Res. 1997;19:241-5. 
7. Gelabert-Gonzalez M, Fernandez-Villa JM, Ginesta-Galan V. Intra-operative monitoring of brain tissue $\mathrm{O}_{2}\left(\mathrm{PtiO}_{2}\right)$ during aneurysm surgery. Acta Neurochir (Wien) 2002;144:863-6; discussion 6-7.

8. Stewart C, Haitsma I, Zador Z, et al. The new Licox combined brain tissue oxygen and brain temperature monitor: assessment of in vitro accuracy and clinical experience in severe traumatic brain injury. Neurosurgery 2008;63:1159-64; discussion 64-5.

9. van den Brink WA, van Santbrink H, Avezaat CJ, et al. Monitoring brain oxygen tension in severe head injury: the Rotterdam experience. Acta Neurochir Suppl. 1998;71:190-4.

10. van Santbrink H, Maas AI, Avezaat CJ. Continuous monitoring of partial pressure of brain tissue oxygen in patients with severe head injury. Neurosurgery. 1996;38:21-31.

11. Scheel M, Dreier JP, Bohner G. Evaluation of intracranial electrocorticography recording strips and tissue partial pressure of oxygen and temperature probes for radio-frequency-induced heating. Acta Neurochir Suppl. 2013;115:149-52.

12. Dengl M, Jaeger M, Renner C, Meixensberger J. Comparing brain tissue oxygen measurements and derived autoregulation parameters from different probes (Licox vs. Raumedic). Acta Neurochir Suppl. 2012;114:165-8.

13. Dengler J, Frenzel C, Vajkoczy P, Wolf S, Horn P. Cerebral tissue oxygenation measured by two different probes: challenges and interpretation. Intensive Care Med. 2011;37:1809-15.

14. Jaeger M, Soehle M, Meixensberger J. Brain tissue oxygen $\left(\mathrm{PtiO}_{2}\right)$ : a clinical comparison of two monitoring devices. Acta Neurochir Suppl. 2005;95:79-81.

15. Purins K, Enblad P, Sandhagen B, Lewen A. Brain tissue oxygen monitoring: a study of in vitro accuracy and stability of Neurovent-PTO and Licox sensors. Acta Neurochir (Wien). 2010;152:681-8.

16. Wolf S, Horn P, Frenzel C, Schurer L, Vajkoczy P, Dengler J. Comparison of a new brain tissue oxygenation probe with the established standard. Acta Neurochir Suppl. 2012;114:161-4.

17. Doppenberg EM, Zauner A, Bullock R, Ward JD, Fatouros PP, Young HF. Correlations between brain tissue oxygen tension, carbon dioxide tension, $\mathrm{pH}$, and cerebral blood flow- a better way of monitoring the severely injured brain? Surg Neurol. 1998;49:650-4.

18. Jaeger M, Dengl M, Meixensberger J, Schuhmann MU. Effects of cerebrovascular pressure reactivity-guided optimization of cerebral perfusion pressure on brain tissue oxygenation after traumatic brain injury. Crit Care Med. 2010;38:1343-7.

19. Jaeger M, Soehle M, Schuhmann MU, Winkler D, Meixensberger J. Correlation of continuously monitored regional cerebral blood flow and brain tissue oxygen. Acta Neurochir (Wien) 2005;147:51-6; discussion 6 .

20. Johnston AJ, Steiner LA, Chatfield DA, et al. Effect of cerebral perfusion pressure augmentation with dopamine and norepinephrine on global and focal brain oxygenation after traumatic brain injury. Intensive Care Med. 2004;30:791-7.

21. Radolovich DK, Czosnyka M, Timofeev I, et al. Reactivity of brain tissue oxygen to change in cerebral perfusion pressure in head injured patients. Neurocrit Care. 2009;10:274-9.

22. Radolovich DK, Czosnyka M, Timofeev I, et al. Transient changes in brain tissue oxygen in response to modifications of cerebral perfusion pressure: an observational study. Anesth Analg. 2010;110:165-73

23. Rosenthal G, Hemphill JC 3rd, Sorani M, et al. Brain tissue oxygen tension is more indicative of oxygen diffusion than oxygen delivery and metabolism in patients with traumatic brain injury. Crit Care Med. 2008;36:1917-24.

24. Stocchetti N, Chieregato A, De Marchi M, Croci M, Benti R, Grimoldi N. High cerebral perfusion pressure improves low values of local brain tissue $\mathrm{O}_{2}$ tension $\left(\mathrm{PtiO}_{2}\right)$ in focal lesions. Acta Neurochir Suppl. 1998;71:162-5.

25. Valadka AB, Hlatky R, Furuya Y, Robertson CS. Brain tissue $\mathrm{PO}_{2}$ : correlation with cerebral blood flow. Acta Neurochir Suppl. 2002;81:299-301.

26. Dohmen C, Bosche B, Graf R, et al. Identification and clinical impact of impaired cerebrovascular autoregulation in patients with malignant middle cerebral artery infarction. Stroke. 2007;38:56-61.

27. Jaeger M, Schuhmann MU, Soehle M, Nagel C, Meixensberger J. Continuous monitoring of cerebrovascular autoregulation after subarachnoid hemorrhage by brain tissue oxygen pressure reactivity and its relation to delayed cerebral infarction. Stroke. 2007;38:981-6.

28. Ko SB, Choi HA, Parikh G, et al. Multimodality monitoring for cerebral perfusion pressure optimization in comatose patients with intracerebral hemorrhage. Stroke. 2011;42:3087-92.

29. Reinert M, Barth A, Rothen HU, Schaller B, Takala J, Seiler RW. Effects of cerebral perfusion pressure and increased fraction of inspired oxygen on brain tissue oxygen, lactate and glucose in patients with severe head injury. Acta Neurochir (Wien) 2003;145:341-9; discussion 9-50.

30. Schmidt JM, Ko SB, Helbok R, et al. Cerebral perfusion pressure thresholds for brain tissue hypoxia and metabolic crisis after poorgrade subarachnoid hemorrhage. Stroke. 2011;42:1351-6.

31. Carmona Suazo JA. Maas AI, van den Brink WA, van Santbrink $\mathrm{H}$, Steyerberg EW, Avezaat CJ. CO2 reactivity and brain oxygen pressure monitoring in severe head injury. Crit Care Med. 2000;28:3268-74.

32. Carrera E, Schmidt JM, Fernandez L, et al. Spontaneous hyperventilation and brain tissue hypoxia in patients with severe brain injury. J Neurol Neurosurg Psychiatry. 2010;81:793-7.

33. Dings J, Meixensberger J, Amschler J, Hamelbeck B, Roosen K. Brain tissue $\mathrm{pO}_{2}$ in relation to cerebral perfusion pressure, TCD findings and $\mathrm{TCD}-\mathrm{CO}_{2}$-reactivity after severe head injury. Acta Neurochir (Wien). 1996;138:425-34.

34. Dings J, Meixensberger J, Amschler J, Roosen K. Continuous monitoring of brain tissue $\mathrm{PO}_{2}$ : a new tool to minimize the risk of ischemia caused by hyperventilation therapy. Zentralbl Neurochir. 1996;57:177-83.

35. Gupta AK, Hutchinson PJ, Fryer T, et al. Measurement of brain tissue oxygenation performed using positron emission tomography scanning to validate a novel monitoring method. J Neurosurg. 2002;96:263-8.

36. Imberti R, Bellinzona G, Langer M. Cerebral tissue $\mathrm{PO}_{2}$ and $\mathrm{SjvO}_{2}$ changes during moderate hyperventilation in patients with severe traumatic brain injury. J Neurosurg. 2002;96:97-102.

37. Maas AI, Fleckenstein W, de Jong DA, van Santbrink H. Monitoring cerebral oxygenation: experimental studies and preliminary clinical results of continuous monitoring of cerebrospinal fluid and brain tissue oxygen tension. Acta Neurochir Suppl (Wien). 1993;59:50-7.

38. Rangel-Castilla L, Lara LR, Gopinath S, Swank PR, Valadka A, Robertson C. Cerebral hemodynamic effects of acute hyperoxia and hyperventilation after severe traumatic brain injury. J Neurotrauma. 2010;27:1853-63.

39. Sarrafzadeh AS, Kiening KL, Callsen TA, Unterberg AW. Metabolic changes during impending and manifest cerebral hypoxia in traumatic brain injury. Br J Neurosurg. 2003;17:340-6.

40. Schneider GH, Sarrafzadeh AS, Kiening KL, Bardt TF, Unterberg AW, Lanksch WR. Influence of hyperventilation on brain tissue- $\mathrm{PO}_{2}, \mathrm{PCO}_{2}$, and $\mathrm{pH}$ in patients with intracranial hypertension. Acta Neurochir Suppl. 1998;71:62-5.

41. Oddo M, Nduom E, Frangos S, et al. Acute lung injury is an independent risk factor for brain hypoxia after severe traumatic brain injury. Neurosurgery. 2010;67:338-44. 
42. Rosenthal G, Hemphill JC, Sorani M, et al. The role of lung function in brain tissue oxygenation following traumatic brain injury. J Neurosurg. 2008;108:59-65.

43. Oddo M, Frangos S, Maloney-Wilensky E, Andrew Kofke W, Le Roux PD, Levine JM. Effect of shivering on brain tissue oxygenation during induced normothermia in patients with severe brain injury. Neurocrit Care. 2010;12:10-6.

44. Stocchetti N, Protti A, Lattuada M, et al. Impact of pyrexia on neurochemistry and cerebral oxygenation after acute brain injury. J Neurol Neurosurg Psychiatry. 2005;76:1135-9.

45. Menon DK, Coles JP, Gupta AK, et al. Diffusion limited oxygen delivery following head injury. Crit Care Med. 2004;32:1384-90.

46. Hoffman WE, Charbel FT, Edelman G, Ausman JI. Brain tissue oxygenation in patients with cerebral occlusive disease and arteriovenous malformations. Br J Anaesth. 1997;78:169-71.

47. Pennings FA, Schuurman PR, van den Munckhof P, Bouma GJ. Brain tissue oxygen pressure monitoring in awake patients during functional neurosurgery: the assessment of normal values. J Neurotrauma. 2008;25:1173-7.

48. Doppenberg EM, Zauner A, Watson JC, Bullock R. Determination of the ischemic threshold for brain oxygen tension. Acta Neurochir Suppl. 1998;71:166-9.

49. Kett-White R, Hutchinson PJ, Al-Rawi PG, et al. Cerebral oxygen and microdialysis monitoring during aneurysm surgery: effects of blood pressure, cerebrospinal fluid drainage, and temporary clipping on infarction. J Neurosurg. 2002;96:1013-9.

50. Sarrafzadeh AS, Sakowitz OW, Callsen TA, Lanksch WR, Unterberg AW. Bedside microdialysis for early detection of cerebral hypoxia in traumatic brain injury. Neurosurg Focus. 2000;9:e2.

51. Brain Trauma F, American Association of Neurological S, Congress of Neurological S, et al. Guidelines for the management of severe traumatic brain injury. X. Brain oxygen monitoring and thresholds. J Neurotrauma 2007;24(Suppl 1):S65-70.

52. Hlatky R, Valadka AB, Gopinath SP, Robertson CS. Brain tissue oxygen tension response to induced hyperoxia reduced in hypoperfused brain. J Neurosurg. 2008;108:53-8.

53. Kiening KL, Schneider GH, Bardt TF, Unterberg AW, Lanksch WR. Bifrontal measurements of brain tissue- $\mathrm{PO}_{2}$ in comatose patients. Acta Neurochir Suppl. 1998;71:172-3.

54. Longhi L, Pagan F, Valeriani V, et al. Monitoring brain tissue oxygen tension in brain-injured patients reveals hypoxic episodes in normal-appearing and in peri-focal tissue. Intensive Care Med. 2007;33:2136-42.

55. Ponce LL, Pillai S, Cruz J, et al. Position of probe determines prognostic information of brain tissue $\mathrm{PO}_{2}$ in severe traumatic brain injury. Neurosurgery 2012;70:1492-502; discussion 502-3.

56. Sarrafzadeh AS, Kiening KL, Bardt TF, Schneider GH, Unterberg AW, Lanksch WR. Cerebral oxygenation in contusioned vs. nonlesioned brain tissue: monitoring of $\mathrm{PtiO}_{2}$ with Licox and Paratrend. Acta Neurochir Suppl. 1998;71:186-9.

57. Ulrich CT, Fung C, Vatter H, et al. Occurrence of vasospasm and infarction in relation to a focal monitoring sensor in patients after SAH: placing a bet when placing a probe? PLoS ONE. 2013;8:e62754.

58. Artru F, Jourdan C, Perret-Liaudet A, Charlot M, Mottolese C. Low brain tissue oxygen pressure: incidence and corrective therapies. Neurol Res. 1998;20(Suppl 1):S48-51.

59. Bruzzone P, Dionigi R, Bellinzona G, Imberti R, Stocchetti N. Effects of cerebral perfusion pressure on brain tissue $\mathrm{PO}_{2}$ in patients with severe head injury. Acta Neurochir Suppl. 1998;71:111-3.

60. Budohoski KP, Zweifel C, Kasprowicz M, et al. What comes first? The dynamics of cerebral oxygenation and blood flow in response to changes in arterial pressure and intracranial pressure after head injury. Br J Anaesth. 2012;108:89-99.

61. Hutchinson PJ, al-Rawi PG, O'Connell MT, et al. Head injury monitoring using cerebral microdialysis and Paratrend multiparameter sensors. Zentralblatt fur Neurochirurgie 2000;61:88-94.

62. Marin-Caballos AJ, Murillo-Cabezas F, Cayuela-Dominguez A, et al. Cerebral perfusion pressure and risk of brain hypoxia in severe head injury: a prospective observational study. Crit Care. 2005;9:R670-6.

63. Kett-White R, Hutchinson PJ, Czosnyka M, et al. Effects of variation in cerebral haemodynamics during aneurysm surgery on brain tissue oxygen and metabolism. Acta Neurochir Suppl. 2002;81:327-9.

64. Vath A, Kunze E, Roosen K, Meixensberger J. Therapeutic aspects of brain tissue $\mathrm{pO}_{2}$ monitoring after subarachnoid hemorrhage. Acta Neurochir Suppl. 2002;81:307-9.

65. Choi HA, Ko SB, Chen H, et al. Acute effects of nimodipine on cerebral vasculature and brain metabolism in high grade subarachnoid hemorrhage patients. Neurocrit Care. 2012;16:363-7.

66. Schiefecker AJ, Pfausler B, Beer R, et al. Parenteral diclofenac infusion significantly decreases brain-tissue oxygen tension in patients with poor-grade aneurysmal subarachnoid hemorrhage. Crit Care. 2013;17:R88.

67. Stiefel MF, Heuer GG, Abrahams JM, et al. The effect of nimodipine on cerebral oxygenation in patients with poor-grade subarachnoid hemorrhage. J Neurosurg. 2004;101:594-9.

68. Johnston AJ, Steiner LA, Coles JP, et al. Effect of cerebral perfusion pressure augmentation on regional oxygenation and metabolism after head injury. Crit Care Med 2005;33:189-95; discussion 255-7.

69. Muench E, Horn P, Bauhuf C, et al. Effects of hypervolemia and hypertension on regional cerebral blood flow, intracranial pressure, and brain tissue oxygenation after subarachnoid hemorrhage. Crit Care Med 2007;35:1844-51; quiz 52.

70. Raabe A, Beck J, Keller M, Vatter H, Zimmermann M, Seifert V. Relative importance of hypertension compared with hypervolemia for increasing cerebral oxygenation in patients with cerebral vasospasm after subarachnoid hemorrhage. J Neurosurg. 2005;103:974-81.

71. Jaeger M, Schuhmann MU, Soehle M, Meixensberger J. Continuous assessment of cerebrovascular autoregulation after traumatic brain injury using brain tissue oxygen pressure reactivity. Crit Care Med. 2006;34:1783-8.

72. Lang EW, Czosnyka M, Mehdorn HM. Tissue oxygen reactivity and cerebral autoregulation after severe traumatic brain injury. Crit Care Med. 2003;31:267-71.

73. Soehle M, Jaeger M, Meixensberger J. Online assessment of brain tissue oxygen autoregulation in traumatic brain injury and subarachnoid hemorrhage. Neurol Res. 2003;25:411-7.

74. Jaeger M, Soehle M, Schuhmann MU, Meixensberger J. Clinical significance of impaired cerebrovascular autoregulation after severe aneurysmal subarachnoid hemorrhage. Stroke. 2012;43:2097-101.

75. Al-Rawi PG, Tseng MY, Richards HK, et al. Hypertonic saline in patients with poor-grade subarachnoid hemorrhage improves cerebral blood flow, brain tissue oxygen, and $\mathrm{pH}$. Stroke. 2010;41:122-8.

76. Al-Rawi PG, Zygun D, Tseng MY, Hutchinson PJ, Matta BF, Kirkpatrick PJ. Cerebral blood flow augmentation in patients with severe subarachnoid haemorrhage. Acta Neurochir Suppl. 2005;95:123-7.

77. Oddo M, Levine JM, Frangos S, et al. Effect of mannitol and hypertonic saline on cerebral oxygenation in patients with 
severe traumatic brain injury and refractory intracranial hypertension. J Neurol Neurosurg Psychiatry. 2009;80:916-20.

78. Francony G, Fauvage B, Falcon D, et al. Equimolar doses of mannitol and hypertonic saline in the treatment of increased intracranial pressure. Crit Care Med. 2008;36:795-800.

79. Gupta AK, Al-Rawi PG, Hutchinson PJ, Kirkpatrick PJ. Effect of hypothermia on brain tissue oxygenation in patients with severe head injury. Br J Anaesth. 2002;88:188-92.

80. Jia J, Lin YQ, Liu WF, et al. Study of the effects of mild hypothermia on cerebral $\mathrm{PO}_{2}, \mathrm{PCO}_{2}$ and $\mathrm{pH}$ and body temperature in patients with acute severe head injury. Chin J Traumatol = Zhonghua chuang shang za zhi/Chinese Medical Association. 2005;8:138-41.

81. Lee HC, Chuang HC, Cho DY, Cheng KF, Lin PH, Chen CC. Applying cerebral hypothermia and brain oxygen monitoring in treating severe traumatic brain injury. World Neurosurg. 2010;74:654-60.

82. Soukup J, Zauner A, Doppenberg EM, et al. Relationship between brain temperature, brain chemistry and oxygen delivery after severe human head injury: the effect of mild hypothermia. Neurol Res. 2002;24:161-8.

83. Zhang S, Zhi D, Lin X, Shang Y, Niu Y. Effect of mild hypothermia on partial pressure of oxygen in brain tissue and brain temperature in patients with severe head injury. Chin J Traumatol $=$ Zhonghua chuang shang $\mathrm{za}$ zhi/Chinese Medical Association. 2002;5:43-5.

84. Chen HI, Malhotra NR, Oddo M, Heuer GG, Levine JM, LeRoux PD. Barbiturate infusion for intractable intracranial hypertension and its effect on brain oxygenation. Neurosurgery 2008;63:880-6; discussion 6-7.

85. Thorat JD, Wang EC, Lee KK, Seow WT, Ng I. Barbiturate therapy for patients with refractory intracranial hypertension following severe traumatic brain injury: its effects on tissue oxygenation, brain temperature and autoregulation. J Clin Neurosci. 2008;15:143-8.

86. Ho CL, Wang CM, Lee KK, Ng I, Ang BT. Cerebral oxygenation, vascular reactivity, and neurochemistry following decompressive craniectomy for severe traumatic brain injury. J Neurosurg. 2008;108:943-9.

87. Jaeger M, Soehle M, Meixensberger J. Improvement of brain tissue oxygen and intracranial pressure during and after surgical decompression for diffuse brain oedema and space occupying infarction. Acta Neurochir Suppl. 2005;95:117-8.

88. Stiefel MF, Heuer GG, Smith MJ, et al. Cerebral oxygenation following decompressive hemicraniectomy for the treatment of refractory intracranial hypertension. J Neurosurg. 2004;101:241-7.

89. Strege RJ, Lang EW, Stark AM, et al. Cerebral edema leading to decompressive craniectomy: an assessment of the preceding clinical and neuromonitoring trends. Neurol Res. 2003;25:510-5.

90. Zhi DS, Zhang S, Zhou LG. Continuous monitoring of brain tissue oxygen pressure in patients with severe head injury during moderate hypothermia. Surg Neurol. 1999;52:393-6.

91. Oddo M, Levine JM, Kumar M, et al. Anemia and brain oxygen after severe traumatic brain injury. Intensive Care Med. 2012;38:1497-504.

92. Kurtz P, Schmidt JM, Claassen J, et al. Anemia is associated with metabolic distress and brain tissue hypoxia after subarachnoid hemorrhage. Neurocrit Care. 2010;13:10-6.

93. Oddo M, Milby A, Chen I, et al. Hemoglobin concentration and cerebral metabolism in patients with aneurysmal subarachnoid hemorrhage. Stroke. 2009;40:1275-81.

94. Leal-Noval SR, Munoz-Gomez M, Arellano-Orden V, et al. Impact of age of transfused blood on cerebral oxygenation in male patients with severe traumatic brain injury. Crit Care Med. 2008;36:1290-6.
95. Leal-Noval SR, Rincon-Ferrari MD, Marin-Niebla A, et al. Transfusion of erythrocyte concentrates produces a variable increment on cerebral oxygenation in patients with severe traumatic brain injury: a preliminary study. Intensive Care Med. 2006;32:1733-40.

96. Smith MJ, Stiefel MF, Magge S, et al. Packed red blood cell transfusion increases local cerebral oxygenation. Crit Care Med. 2005;33:1104-8.

97. Zygun DA, Nortje J, Hutchinson PJ, Timofeev I, Menon DK, Gupta AK. The effect of red blood cell transfusion on cerebral oxygenation and metabolism after severe traumatic brain injury. Crit Care Med. 2009;37:1074-8.

98. Edelman GJ, Hoffman WE, Charbel FT. Cerebral hypoxia after etomidate administration and temporary cerebral artery occlusion. Anesth Analg. 1997;85:821-5.

99. Helbok R, Kurtz P, Schmidt MJ, et al. Effects of the neurological wake-up test on clinical examination, intracranial pressure, brain metabolism and brain tissue oxygenation in severely brain-injured patients. Crit Care. 2012;16:R226.

100. Hoffman WE, Charbel FT, Edelman G. Desflurane increases brain tissue oxygenation and $\mathrm{pH}$. Acta Anaesthesiol Scand. 1997;41:1162-6.

101. Hoffman WE, Wheeler P, Edelman G, Charbel FT, Torres NJ, Ausman JI. Hypoxic brain tissue following subarachnoid hemorrhage. Anesthesiology. 2000;92:442-6.

102. James ML, Olson DM, Graffagnino C. A pilot study of cerebral and haemodynamic physiological changes during sedation with dexmedetomidine or propofol in patients with acute brain injury. Anaesth Intensive Care. 2012;40:949-57.

103. Johnston AJ, Steiner LA, Chatfield DA, et al. Effects of propofol on cerebral oxygenation and metabolism after head injury. Br J Anaesth. 2003;91:781-6.

104. Skoglund K, Hillered L, Purins K, et al. The neurological wakeup test does not alter cerebral energy metabolism and oxygenation in patients with severe traumatic brain injury. Neurocrit Care. 2014;20:413-26.

105. Zhang XY, Yang ZJ, Wang QX, Fan HR. Impact of positive end-expiratory pressure on cerebral injury patients with hypoxemia. Am J Emerg Med. 2011;29:699-703.

106. Reinprecht A, Greher M, Wolfsberger S, Dietrich W, Illievich UM, Gruber A. Prone position in subarachnoid hemorrhage patients with acute respiratory distress syndrome: effects on cerebral tissue oxygenation and intracranial pressure. Crit Care Med. 2003;31:1831-8.

107. Wolf S, Plev DV, Trost HA, Lumenta CB. Open lung ventilation in neurosurgery: an update on brain tissue oxygenation. Acta Neurochir Suppl. 2005;95:103-5.

108. Muench E, Bauhuf C, Roth H, et al. Effects of positive endexpiratory pressure on regional cerebral blood flow, intracranial pressure, and brain tissue oxygenation. Crit Care Med. 2005;33:2367-72.

109. Cerejo A, Silva PA, Vilarinho A, Dias C, Vaz R. Intraoperative brain oxygenation monitoring and vasospasm in aneurysmal subarachnoid hemorrhage. Neurol Res. 2012;34:181-6.

110. Charbel FT, Du X, Hoffman WE, Ausman JI. Brain tissue $\mathrm{PO}(2), \mathrm{PCO}(2)$, and $\mathrm{pH}$ during cerebral vasospasm. Surg Neurol. 2000;54:432-7 discussion 8 .

111. Deshaies EM, Jacobsen W, Singla A, Li F, Gorji R. Brain tissue oxygen monitoring to assess reperfusion after intra-arterial treatment of aneurysmal subarachnoid hemorrhage-induced cerebral vasospasm: a retrospective study. AJNR Am J Neuroradiol. 2012;33:1411-5.

112. Helbok R, Shaker E, Beer R, et al. High dose erythropoietin increases brain tissue oxygen tension in severe vasospasm after subarachnoid hemorrhage. BMC Neurol. 2012;12:32. 
113. Imberti R, Fuardo M, Bellinzona G, Pagani M, Langer M. The use of indomethacin in the treatment of plateau waves: effects on cerebral perfusion and oxygenation. $\mathrm{J}$ Neurosurg. 2005;102:455-9.

114. Kett-White R, Hutchinson PJ, Al-Rawi PG, Gupta AK, Pickard JD, Kirkpatrick PJ. Adverse cerebral events detected after subarachnoid hemorrhage using brain oxygen and microdialysis probes. Neurosurgery 2002;50:1213-21; discussion 21-2.

115. Raabe A, Zimmermann M, Setzer M, Vatter H, Berkefeld J, Seifert V. Effect of intraventricular sodium nitroprusside on cerebral hemodynamics and oxygenation in poor-grade aneurysm patients with severe, medically refractory vasospasm. Neurosurgery 2002;50:1006-13; discussion 13-4.

116. Stiefel MF, Spiotta AM, Udoetuk JD, et al. Intra-arterial papaverine used to treat cerebral vasospasm reduces brain oxygen. Neurocrit Care. 2006;4:113-8.

117. Stuart RM, Helbok R, Kurtz $P$, et al. High-dose intra-arterial verapamil for the treatment of cerebral vasospasm after subarachnoid hemorrhage: prolonged effects on hemodynamic parameters and brain metabolism. Neurosurgery 2011;68:337-45; discussion 45.

118. Ang BT, Wong J, Lee KK, Wang E, Ng I. Temporal changes in cerebral tissue oxygenation with cerebrovascular pressure reactivity in severe traumatic brain injury. J Neurol Neurosurg Psychiatry. 2007;78:298-302.

119. Eriksson EA, Barletta JF, Figueroa BE, et al. The first 72 hours of brain tissue oxygenation predicts patient survival with traumatic brain injury. J Trauma Acute Care Surg. 2012;72:1345-9.

120. Eriksson EA, Barletta JF, Figueroa BE, et al. Cerebral perfusion pressure and intracranial pressure are not surrogates for brain tissue oxygenation in traumatic brain injury. Clin Neurophysiol Off J Int Federation Clin Neurophysiol. 2012;123:1255-60.

121. Li W, Cai X, Wang J, Chen G, Chai Z. Early monitoring of $\mathrm{P}(\mathrm{ti}) \mathrm{O}(2), \mathrm{P}(\mathrm{ti}) \mathrm{CO}(2), \mathrm{pH}$ and brain temperature in patients with brain injuries and the clinical significance. Chinese J Traumatol = Zhonghua chuang shang za zhi/Chinese Medical Association. 2001;4:20-4.

122. Stiefel MF, Udoetuk JD, Spiotta AM, et al. Conventional neurocritical care and cerebral oxygenation after traumatic brain injury. J Neurosurg. 2006;105:568-75.

123. Valadka AB, Gopinath SP, Contant CF, Uzura M, Robertson CS. Relationship of brain tissue $\mathrm{PO}_{2}$ to outcome after severe head injury. Crit Care Med. 1998;26:1576-81.

124. Bardt TF, Unterberg AW, Hartl R, Kiening KL, Schneider GH, Lanksch WR. Monitoring of brain tissue $\mathrm{PO}_{2}$ in traumatic brain injury: effect of cerebral hypoxia on outcome. Acta Neurochir Suppl. 1998;71:153-6.

125. Chang JJ, Youn TS, Benson D, et al. Physiologic and functional outcome correlates of brain tissue hypoxia in traumatic brain injury. Crit Care Med. 2009;37:283-90.

126. Dings J, Jager A, Meixensberger J, Roosen K. Brain tissue $\mathrm{pO}_{2}$ and outcome after severe head injury. Neurol Res. 1998; 20(Suppl 1):S71-5.

127. Hlatky R, Valadka AB, Goodman JC, Robertson CS. Evolution of brain tissue injury after evacuation of acute traumatic subdural hematomas. Neurosurgery 2004;55:1318-23; discussion 24.

128. Oddo M, Levine JM, Mackenzie L, et al. Brain hypoxia is associated with short-term outcome after severe traumatic brain injury independent of intracranial hypertension and low cerebral perfusion pressure. Neurosurgery. 2011;69:1037-45; discussion 1045.

129. van den Brink WA, van Santbrink H, Steyerberg EW, et al. Brain oxygen tension in severe head injury. Neurosurgery 2000;46:868-76; discussion 76-8.
130. Vath A, Meixensberger J, Dings J, Roosen K. Advanced neuromonitoring including cerebral tissue oxygenation and outcome after traumatic brain injury. Neurol Res. 2001;23:315-20.

131. Meixensberger J, Renner C, Simanowski R, Schmidtke A, Dings J, Roosen K. Influence of cerebral oxygenation following severe head injury on neuropsychological testing. Neurol Res. 2004;26:414-7.

132. Egea-Guerrero JJ, Gordillo-Escobar E, Revuelto-Rey J, et al. Clinical variables and neuromonitoring information (intracranial pressure and brain tissue oxygenation) as predictors of braindeath development after severe traumatic brain injury. Transplant Proc. 2012;44:2050-2.

133. Palmer S, Bader MK. Brain tissue oxygenation in brain death. Neurocrit Care. 2005;2:17-22.

134. Jaeger M, Lang EW. Cerebrovascular pressure reactivity and cerebral oxygen regulation after severe head injury. Neurocrit Care. 2013;19:69-73.

135. Menzel M, Doppenberg EM, Zauner A, et al. Cerebral oxygenation in patients after severe head injury: monitoring and effects of arterial hyperoxia on cerebral blood flow, metabolism and intracranial pressure. J Neurosurg Anesthesiol. 1999;11:240-51.

136. van Santbrink H, vd Brink WA, Steyerberg EW, Carmona Suazo JA, Avezaat CJ, Maas AI. Brain tissue oxygen response in severe traumatic brain injury. Acta Neurochir (Wien) 2003;145:429-38; discussion 38.

137. Meixensberger J, Vath A, Jaeger M, Kunze E, Dings J, Roosen $\mathrm{K}$. Monitoring of brain tissue oxygenation following severe subarachnoid hemorrhage. Neurol Res. 2003;25:445-50.

138. Ramakrishna R, Stiefel M, Udoetuk J, et al. Brain oxygen tension and outcome in patients with aneurysmal subarachnoid hemorrhage. J Neurosurg. 2008;109:1075-82.

139. Bohman LE, Heuer GG, Macyszyn L, et al. Medical management of compromised brain oxygen in patients with severe traumatic brain injury. Neurocrit Care. 2011;14:361-9.

140. Pascual JL, Georgoff P, Maloney-Wilensky E, et al. Reduced brain tissue oxygen in traumatic brain injury: are most commonly used interventions successful? J Trauma. 2011;70: 535-46.

141. Longhi L, Valeriani V, Rossi S, De Marchi M, Egidi M, Stocchetti N. Effects of hyperoxia on brain tissue oxygen tension in cerebral focal lesions. Acta Neurochir Suppl. 2002;81:315-7.

142. Menzel M, Doppenberg EM, Zauner A, Soukup J, Reinert MM, Bullock R. Increased inspired oxygen concentration as a factor in improved brain tissue oxygenation and tissue lactate levels after severe human head injury. J Neurosurg. 1999;91:1-10.

143. Nortje J, Coles JP, Timofeev I, et al. Effect of hyperoxia on regional oxygenation and metabolism after severe traumatic brain injury: preliminary findings. Crit Care Med. 2008;36: 273-81.

144. Puccio AM, Hoffman LA, Bayir H, et al. Effect of short periods of normobaric hyperoxia on local brain tissue oxygenation and cerebrospinal fluid oxidative stress markers in severe traumatic brain injury. J Neurotrauma. 2009;26:1241-9.

145. Rockswold SB, Rockswold GL, Zaun DA, Liu J. A prospective, randomized Phase II clinical trial to evaluate the effect of combined hyperbaric and normobaric hyperoxia on cerebral metabolism, intracranial pressure, oxygen toxicity, and clinical outcome in severe traumatic brain injury. J Neurosurg. 2013;118:1317-28.

146. Rockswold SB, Rockswold GL, Zaun DA, et al. A prospective, randomized clinical trial to compare the effect of hyperbaric to normobaric hyperoxia on cerebral metabolism, intracranial pressure, and oxygen toxicity in severe traumatic brain injury. J Neurosurg. 2010;112:1080-94. 
147. Tisdall MM, Tachtsidis I, Leung TS, Elwell CE, Smith M. Increase in cerebral aerobic metabolism by normobaric hyperoxia after traumatic brain injury. J Neurosurg. 2008;109:424-32.

148. Tolias CM, Reinert M, Seiler R, Gilman C, Scharf A, Bullock MR. Normobaric hyperoxia-induced improvement in cerebral metabolism and reduction in intracranial pressure in patients with severe head injury: a prospective historical cohort-matched study. J Neurosurg. 2004;101:435-44.

149. Vilalta A, Sahuquillo J, Merino MA, et al. Normobaric hyperoxia in traumatic brain injury: does brain metabolic state influence the response to hyperoxic challenge? J Neurotrauma. 2011;28:1139-48.

150. Bohman LE, Pisapia JM, Sanborn MR, et al. Response of brain oxygen to therapy correlates with long-term outcome after subarachnoid hemorrhage. Neurocrit Care. 2013;19:320-8.

151. Adamides AA, Cooper DJ, Rosenfeldt FL, et al. Focal cerebral oxygenation and neurological outcome with or without brain tissue oxygen-guided therapy in patients with traumatic brain injury. Acta Neurochir (Wien). 2009;151:1399-409.

152. Fletcher JJ, Bergman K, Blostein PA, Kramer AH. Fluid balance, complications, and brain tissue oxygen tension monitoring following severe traumatic brain injury. Neurocrit Care. 2010;13:47-56.

153. Green JA, Pellegrini DC, Vanderkolk WE, Figueroa BE, Eriksson EA. Goal directed brain tissue oxygen monitoring versus conventional management in traumatic brain injury: an analysis of in hospital recovery. Neurocrit Care. 2013;18:20-5.

154. Martini RP, Deem S, Yanez ND, et al. Management guided by brain tissue oxygen monitoring and outcome following severe traumatic brain injury. J Neurosurg. 2009;111:644-9.

155. McCarthy MC, Moncrief H, Sands JM, et al. Neurologic outcomes with cerebral oxygen monitoring in traumatic brain injury. Surgery 2009;146:585-90; discussion 90-1.

156. Meixensberger J, Jaeger M, Vath A, Dings J, Kunze E, Roosen $\mathrm{K}$. Brain tissue oxygen guided treatment supplementing ICP/ CPP therapy after traumatic brain injury. J Neurol Neurosurg Psychiatry. 2003;74:760-4.

157. Narotam PK, Morrison JF, Nathoo N. Brain tissue oxygen monitoring in traumatic brain injury and major trauma: outcome analysis of a brain tissue oxygen-directed therapy. J Neurosurg. 2009;111:672-82.

158. Spiotta AM, Stiefel MF, Gracias VH, et al. Brain tissue oxygendirected management and outcome in patients with severe traumatic brain injury. J Neurosurg. 2010;113:571-80.

159. Stiefel MF, Spiotta A, Gracias VH, et al. Reduced mortality rate in patients with severe traumatic brain injury treated with brain tissue oxygen monitoring. J Neurosurg. 2005;103:805-11.

160. Howard L, Gopinath SP, Uzura M, Valadka A, Robertson CS. Evaluation of a new fiberoptic catheter for monitoring jugular venous oxygen saturation. Neurosurgery. 1999;44:1280-5.

161. Lam JM, Chan MS, Poon WS. Cerebral venous oxygen saturation monitoring: is dominant jugular bulb cannulation good enough? Br J Neurosurg. 1996;10:357-64.

162. Metz C, Holzschuh M, Bein T, et al. Monitoring of cerebral oxygen metabolism in the jugular bulb: reliability of unilateral measurements in severe head injury. J Cereb Blood Flow Metab. 1998;18:332-43.

163. Stocchetti N, Paparella A, Bridelli F, Bacchi M, Piazza P, Zuccoli P. Cerebral venous oxygen saturation studied with bilateral samples in the internal jugular veins. Neurosurgery 1994;34:38-43; discussion 4.

164. Bankier AA, Fleischmann D, Windisch A, et al. Position of jugular oxygen saturation catheter in patients with head trauma: assessment by use of plain films. AJR Am J Roentgenol. 1995;164:437-41.

165. Bhatia A, Gupta AK. Neuromonitoring in the intensive care unit. I. Intracranial pressure and cerebral blood flow monitoring. Intensive Care Med. 2007;33:1263-71.
166. Steiner LA, Andrews PJ. Monitoring the injured brain: ICP and CBF. Br J Anaesth. 2006;97:26-38.

167. Coplin WM, O'Keefe GE, Grady MS, et al. Thrombotic, infectious, and procedural complications of the jugular bulb catheter in the intensive care unit. Neurosurgery 1997;41:101-7; discussion 7-9.

168. Goetting MG, Preston G. Jugular bulb catheterization does not increase intracranial pressure. Intensive Care Med. 1991;17: 195-8.

169. Latronico N, Beindorf AE, Rasulo FA, et al. Limits of intermittent jugular bulb oxygen saturation monitoring in the management of severe head trauma patients. Neurosurgery. 2000;46:1131-8 discussion 8-9.

170. Matta BF, Lam AM. The rate of blood withdrawal affects the accuracy of jugular venous bulb. Oxygen saturation measurements. Anesthesiology. 1997;86:806-8.

171. Ritter AM, Gopinath SP, Contant C, Narayan RK, Robertson CS. Evaluation of a regional oxygen saturation catheter for monitoring $\mathrm{SjvO}_{2}$ in head injured patients. J Clin Monit. 1996;12:285-91.

172. Kiening KL, Unterberg AW, Bardt TF, Schneider GH, Lanksch WR. Monitoring of cerebral oxygenation in patients with severe head injuries: brain tissue $\mathrm{PO}_{2}$ versus jugular vein oxygen saturation. J Neurosurg. 1996;85:751-7.

173. Souter MJ, Andrews PJ. Validation of the Edslab dual lumen oximetry catheter for continuous monitoring of jugular bulb oxygen saturation after severe head injury. $\mathrm{Br} \mathrm{J}$ Anaesth. 1996;76:744-6.

174. Fandino J, Stocker R, Prokop S, Imhof HG. Correlation between jugular bulb oxygen saturation and partial pressure of brain tissue oxygen during $\mathrm{CO}_{2}$ and $\mathrm{O}_{2}$ reactivity tests in severely head-injured patients. Acta Neurochir (Wien). 1999;141: 825-34.

175. Filippi R, Reisch R, Mauer D, Perneczky A. Brain tissue $\mathrm{pO}_{2}$ related to $\mathrm{SjvO}_{2}$, ICP, and CPP in severe brain injury. Neurosurg Rev. 2000;23:94-7.

176. Gopinath SP, Valadka AB, Uzura M, Robertson CS. Comparison of jugular venous oxygen saturation and brain tissue $\mathrm{PO}_{2}$ as monitors of cerebral ischemia after head injury. Crit Care Med. 1999;27:2337-45.

177. Gupta AK, Hutchinson PJ, Al-Rawi P, et al. Measuring brain tissue oxygenation compared with jugular venous oxygen saturation for monitoring cerebral oxygenation after traumatic brain injury. Anesth Analg. 1999;88:549-53.

178. Meixensberger J, Jager A, Dings J, Baunach S, Roosen K. Multimodal hemodynamic neuromonitoring-quality and consequences for therapy of severely head injured patients. Acta Neurochir Suppl. 1998;71:260-2.

179. Robertson CS, Gopinath SP, Uzura M, Valadka AB, Goodman JC. Metabolic changes in the brain during transient ischemia measured with microdialysis. Neurol Res. 1998;20(Suppl 1):S91-4.

180. Cormio M, Valadka AB, Robertson CS. Elevated jugular venous oxygen saturation after severe head injury. J Neurosurg. 1999;90:9-15.

181. Fandino J, Stocker R, Prokop S, Trentz O, Imhof HG. Cerebral oxygenation and systemic trauma related factors determining neurological outcome after brain injury. J Clin Neurosci. 2000;7:226-33.

182. Gopinath SP, Robertson CS, Contant CF, et al. Jugular venous desaturation and outcome after head injury. J Neurol Neurosurg Psychiatry. 1994;57:717-23.

183. Moritz S, Kasprzak P, Woertgen C, Taeger K, Metz C. The accuracy of jugular bulb venous monitoring in detecting cerebral ischemia in awake patients undergoing carotid endarterectomy. J Neurosurg Anesthesiol. 2008;20:8-14. 
184. Schoon P, Benito Mori L, Orlandi G, Larralde C, Radrizzani M. Incidence of intracranial hypertension related to jugular bulb oxygen saturation disturbances in severe traumatic brain injury patients. Acta Neurochir Suppl. 2002;81:285-7.

185. Stocchetti N, Canavesi K, Magnoni S, et al. Arterio-jugular difference of oxygen content and outcome after head injury. Anesth Analg. 2004;99:230-4.

186. Coles JP, Fryer TD, Coleman MR, et al. Hyperventilation following head injury: effect on ischemic burden and cerebral oxidative metabolism. Crit Care Med. 2007;35:568-78.

187. Coles JP, Fryer TD, Smielewski P, et al. Incidence and mechanisms of cerebral ischemia in early clinical head injury. J Cereb Blood Flow Metab. 2004;24:202-11.

188. Coles JP, Minhas PS, Fryer TD, et al. Effect of hyperventilation on cerebral blood flow in traumatic head injury: clinical relevance and monitoring correlates. Crit Care Med. 2002;30:1950-9.

189. Gopinath SP, Valadka A, Contant CF, Robertson CS. Relationship between global and cortical cerebral blood flow in patients with head injuries. Neurosurgery 1999;44:1273-8; discussion 8-9.

190. Keller E, Steiner T, Fandino J, Schwab S, Hacke W. Jugular venous oxygen saturation thresholds in trauma patients may not extrapolate to ischemic stroke patients: lessons from a preliminary study. J Neurosurg Anesthesiol. 2002;14:130-6.

191. Robertson CS, Narayan RK, Gokaslan ZL, et al. Cerebral arteriovenous oxygen difference as an estimate of cerebral blood flow in comatose patients. J Neurosurg. 1989;70:222-30.

192. Chan KH, Dearden NM, Miller JD, Andrews PJ, Midgley S. Multimodality monitoring as a guide to treatment of intracranial hypertension after severe brain injury. Neurosurgery 1993;32:547-52; discussion 52-3.

193. Chieregato A, Marchi M, Zoppellari R, et al. Detection of early ischemia in severe head injury by means of arteriovenous lactate differences and jugular bulb oxygen saturation. Relationship with CPP, severity indexes and outcome. Preliminary analysis. Acta Neurochir Suppl. 2002;81:289-93.

194. De Deyne C, Decruyenaere J, Calle P, et al. Analysis of very early jugular bulb oximetry data after severe head injury: implications for the emergency management? Eur J Emerg Med. 1996;3:69-72.

195. Lewis SB, Myburgh JA, Reilly PL. Detection of cerebral venous desaturation by continuous jugular bulb oximetry following acute neurotrauma. Anaesth Intensive Care. 1995;23:307-14.

196. Schneider GH, von Helden A, Lanksch WR, Unterberg A. Continuous monitoring of jugular bulb oxygen saturation in comatose patients-therapeutic implications. Acta Neurochir (Wien). 1995;134:71-5.

197. Vigue B, Ract C, Benayed M, et al. Early $\mathrm{SjvO}_{2}$ monitoring in patients with severe brain trauma. Intensive Care Med. 1999;25:445-51.

198. Vuille-Dit-Bille RN, Ha-Huy R, Tanner M, Stover JF. Changes in calculated arterio-jugular venous glutamate difference and $\mathrm{SjvO}_{2}$ in patients with severe traumatic brain injury. Minerva Anestesiol. 2011;77:870-6.

199. Fortune JB, Feustel PJ, Weigle CG, Popp AJ. Continuous measurement of jugular venous oxygen saturation in response to transient elevations of blood pressure in head-injured patients. J Neurosurg. 1994;80:461-8.

200. Robertson CS, Valadka AB, Hannay HJ, et al. Prevention of secondary ischemic insults after severe head injury. Crit Care Med. 1999;27:2086-95.

201. Citerio G, Cormio M, Portella G, Vascotto E, Galli D, Gaini SM. Jugular saturation $\left(\mathrm{SjvO}_{2}\right)$ monitoring in subarachnoid hemorrhage (SAH). Acta Neurochir Suppl. 1998; $71: 316-9$
202. Robertson CS, Gopinath SP, Goodman JC, Contant CF, Valadka $\mathrm{AB}$, Narayan RK. $\mathrm{SjvO}_{2}$ monitoring in head-injured patients. J Neurotrauma. 1995; 12:891-6.

203. Bouma GJ, Muizelaar JP, Choi SC, Newlon PG, Young HF. Cerebral circulation and metabolism after severe traumatic brain injury: the elusive role of ischemia. J Neurosurg. 1991;75:685-93.

204. Fortune JB, Feustel PJ, Graca L, Hasselbarth J, Kuehler DH. Effect of hyperventilation, mannitol, and ventriculostomy drainage on cerebral blood flow after head injury. J Trauma 1995;39:1091-7; discussion 7-9.

205. Nakamura T, Nagao S, Kawai N, Honma Y, Kuyama H. Significance of multimodal cerebral monitoring under moderate therapeutic hypothermia for severe head injury. Acta Neurochir Suppl. 1998;71:85-7.

206. Tokutomi T, Morimoto K, Miyagi T, Yamaguchi S, Ishikawa K, Shigemori M. Optimal temperature for the management of severe traumatic brain injury: effect of hypothermia on intracranial pressure, systemic and intracranial hemodynamics, and metabolism. Neurosurgery 2007;61:256-65; discussion 65-6.

207. de Deyne C, Vandekerckhove T, Decruyenaere J, Colardyn F. Analysis of abnormal jugular bulb oxygen saturation data in patients with severe head injury. Acta Neurochir (Wien). 1996;138:1409-15.

208. Obrist WD, Langfitt TW, Jaggi JL, Cruz J, Gennarelli TA. Cerebral blood flow and metabolism in comatose patients with acute head injury. Relationship to intracranial hypertension. J Neurosurg. 1984;61:241-53.

209. Sahuquillo J, Poca MA, Ausina A, Baguena M, Gracia RM, Rubio E. Arterio-jugular differences of oxygen (AVDO2) for bedside assessment of $\mathrm{CO}_{2}$-reactivity and autoregulation in the acute phase of severe head injury. Acta Neurochir (Wien). 1996;138:435-44.

210. Schaffranietz L, Heinke W. The effect of different ventilation regimes on jugular venous oxygen saturation in elective neurosurgical patients. Neurol Res. 1998;20(Suppl 1):S66-70.

211. Thiagarajan A, Goverdhan PD, Chari P, Somasunderam K. The effect of hyperventilation and hyperoxia on cerebral venous oxygen saturation in patients with traumatic brain injury. Anesth Analg. 1998;87:850-3.

212. von Helden A, Schneider GH, Unterberg A, Lanksch WR. Monitoring of jugular venous oxygen saturation in comatose patients with subarachnoid haemorrhage and intracerebral haematomas. Acta Neurochir Suppl (Wien). 1993;59:102-6.

213. Le Roux PD, Newell DW, Lam AM, Grady MS, Winn HR. Cerebral arteriovenous oxygen difference: a predictor of cerebral infarction and outcome in patients with severe head injury. J Neurosurg. 1997;87:1-8.

214. Albanese J, Viviand X, Potie F, Rey M, Alliez B, Martin C. Sufentanil, fentanyl, and alfentanil in head trauma patients: a study on cerebral hemodynamics. Crit Care Med. 1999;27:407-11.

215. Iwata M, Kawaguchi M, Inoue S, et al. Effects of increasing concentrations of propofol on jugular venous bulb oxygen saturation in neurosurgical patients under normothermic and mildly hypothermic conditions. Anesthesiology. 2006;104:33-8.

216. Heran NS, Hentschel SJ, Toyota BD. Jugular bulb oximetry for prediction of vasospasm following subarachnoid hemorrhage. Can J Neurol Sci. 2004;31:80-6.

217. Robertson C. Desaturation episodes after severe head injury: influence on outcome. Acta Neurochir Suppl (Wien). 1993;59:98-101.

218. Chieregato A, Marchi M, Fainardi E, Targa L. Cerebral arteriovenous $\mathrm{pCO}_{2}$ difference, estimated respiratory quotient, and early posttraumatic outcome: comparison with arterio-venous lactate and oxygen differences. J Neurosurg Anesthesiol. 2007;19:222-8. 
219. Buchner K, Meixensberger J, Dings J, Roosen K. Near-infrared spectroscopy-not useful to monitor cerebral oxygenation after severe brain injury. Zentralbl Neurochir. 2000;61:69-73.

220. Davie SN, Grocott HP. Impact of extracranial contamination on regional cerebral oxygen saturation: a comparison of three cerebral oximetry technologies. Anesthesiology. 2012;116:83440.

221. Naidech AM, Bendok BR, Ault ML, Bleck TP. Monitoring with the Somanetics INVOS 5100C after aneurysmal subarachnoid hemorrhage. Neurocrit Care. 2008;9:326-31.

222. Taussky P, O'Neal B, Daugherty WP, et al. Validation of frontal near-infrared spectroscopy as noninvasive bedside monitoring for regional cerebral blood flow in brain-injured patients. Neurosurg Focus. 2012;32:E2.

223. Yoshitani K, Kawaguchi M, Miura N, et al. Effects of hemoglobin concentration, skull thickness, and the area of the cerebrospinal fluid layer on near-infrared spectroscopy measurements. Anesthesiology. 2007;106:458-62.

224. Germon TJ, Young AE, Manara AR, Nelson RJ. Extracerebral absorption of near infrared light influences the detection of increased cerebral oxygenation monitored by near infrared spectroscopy. J Neurol Neurosurg Psychiatry. 1995;58:477-9.

225. Ghosh A, Elwell C, Smith M. Review article: cerebral nearinfrared spectroscopy in adults: a work in progress. Anesth Analg. 2012;115:1373-83.

226. Gomersall CD, Leung PL, Gin T, et al. A comparison of the Hamamatsu NIRO 500 and the INVOS 3100 near-infrared spectrophotometers. Anaesth Intensive Care. 1998;26:548-57.

227. Grubhofer G, Lassnigg A, Manlik F, Marx E, Trubel W, Hiesmayr $M$. The contribution of extracranial blood oxygenation on nearinfrared spectroscopy during carotid thrombendarterectomy. Anaesthesia. 1997;52:116-20.

228. Highton D, Elwell C, Smith M. Noninvasive cerebral oximetry: is there light at the end of the tunnel? Curr Opin Anaesthesiol. 2010;23:576-81.

229. Kim MB, Ward DS, Cartwright CR, Kolano J, Chlebowski S, Henson LC. Estimation of jugular venous $\mathrm{O}_{2}$ saturation from cerebral oximetry or arterial $\mathrm{O}_{2}$ saturation during isocapnic hypoxia. J Clin Monit Comput. 2000;16:191-9.

230. McCormick PW, Stewart M, Goetting MG, Dujovny M, Lewis G, Ausman JI. Noninvasive cerebral optical spectroscopy for monitoring cerebral oxygen delivery and hemodynamics. Crit Care Med. 1991;19:89-97.

231. Pollard V, Prough DS, DeMelo AE, Deyo DJ, Uchida T, Stoddart HF. Validation in volunteers of a near-infrared spectroscope for monitoring brain oxygenation in vivo. Anesth Analg. 1996;82:269-77.

232. Pollard V, Prough DS, DeMelo AE, Deyo DJ, Uchida T, Widman R. The influence of carbon dioxide and body position on near-infrared spectroscopic assessment of cerebral hemoglobin oxygen saturation. Anesth Analg. 1996;82:278-87.

233. Samra SK, Stanley JC, Zelenock GB, Dorje P. An assessment of contributions made by extracranial tissues during cerebral oximetry. J Neurosurg Anesthesiol. 1999;11:1-5.

234. Schwarz G, Litscher G, Kleinert R, Jobstmann R. Cerebral oximetry in dead subjects. J Neurosurg Anesthesiol. 1996;8:189-93.

235. Tachtsidis I, Tisdall MM, Leung TS, et al. Relationship between brain tissue haemodynamics, oxygenation and metabolism in the healthy human adult brain during hyperoxia and hypercapnea. Adv Exp Med Biol. 2009;645:315-20.

236. Tisdall MM, Tachtsidis I, Leung TS, Elwell CE, Smith M. Changes in the attenuation of near infrared spectra by the healthy adult brain during hypoxaemia cannot be accounted for solely by changes in the concentrations of oxy- and deoxyhaemoglobin. Adv Exp Med Biol. 2008;614:217-25.
237. Yoshitani K, Kawaguchi M, Tatsumi K, Kitaguchi K, Furuya H. A comparison of the INVOS 4100 and the NIRO 300 nearinfrared spectrophotometers. Anesth Analg 2002;94:586-90; table of contents.

238. Kirkpatrick PJ, Lam J, Al-Rawi P, Smielewski P, Czosnyka M. Defining thresholds for critical ischemia by using near-infrared spectroscopy in the adult brain. J Neurosurg. 1998;89:389-94.

239. Bhatia R, Hampton T, Malde $S$, et al. The application of nearinfrared oximetry to cerebral monitoring during aneurysm embolization: a comparison with intraprocedural angiography. J Neurosurg Anesthesiol. 2007;19:97-104.

240. Brawanski A, Faltermeier R, Rothoerl RD, Woertgen C. Comparison of near-infrared spectroscopy and tissue $\mathrm{p}\left(\mathrm{O}_{2}\right)$ time series in patients after severe head injury and aneurysmal subarachnoid hemorrhage. J Cereb Blood Flow Metab. 2002;22:605-11.

241. Horie N, Kitagawa N, Morikawa M, Kaminogo M, Nagata I. Monitoring of regional cerebral oxygenation by near-infrared spectroscopy in carotid arterial stenting: preliminary study. Neuroradiology. 2005;47:375-9.

242. Komoribayashi N, Ogasawara K, Kobayashi M, et al. Cerebral hyperperfusion after carotid endarterectomy is associated with preoperative hemodynamic impairment and intraoperative cerebral ischemia. J Cereb Blood Flow Metab. 2006;26:878-84.

243. Matsumoto S, Nakahara I, Higashi T, et al. Near-infrared spectroscopy in carotid artery stenting predicts cerebral hyperperfusion syndrome. Neurology. 2009;72:1512-8.

244. McLeod AD, Igielman F, Elwell C, Cope M, Smith M. Measuring cerebral oxygenation during normobaric hyperoxia: a comparison of tissue microprobes, near-infrared spectroscopy, and jugular venous oximetry in head injury. Anesth Analg. 2003;97:851-6.

245. Moritz S, Kasprzak P, Arlt M, Taeger K, Metz C. Accuracy of cerebral monitoring in detecting cerebral ischemia during carotid endarterectomy: a comparison of transcranial Doppler sonography, near-infrared spectroscopy, stump pressure, and somatosensory evoked potentials. Anesthesiology. 2007;107:563-9.

246. Ogasawara K, Konno H, Yukawa H, Endo H, Inoue T, Ogawa A. Transcranial regional cerebral oxygen saturation monitoring during carotid endarterectomy as a predictor of postoperative hyperperfusion. Neurosurgery 2003;53:309-14; discussion 14-5.

247. Pennekamp CW, Immink RV, den Ruijter HM, et al. Nearinfrared spectroscopy can predict the onset of cerebral hyperperfusion syndrome after carotid endarterectomy. Cerebrovasc Dis. 2012;34:314-21.

248. Zweifel C, Castellani G, Czosnyka M, et al. Continuous assessment of cerebral autoregulation with near-infrared spectroscopy in adults after subarachnoid hemorrhage. Stroke. 2010; 41:1963-8.

249. Zweifel C, Castellani G, Czosnyka M, et al. Noninvasive monitoring of cerebrovascular reactivity with near infrared spectroscopy in head-injured patients. J Neurotrauma. 2010;27: 1951-8.

250. Pennekamp CW, Bots ML, Kappelle LJ, Moll FL, de Borst GJ. The value of near-infrared spectroscopy measured cerebral oximetry during carotid endarterectomy in perioperative stroke prevention. A review. Eur J Vasc Endovasc Surg. 2009;38:539-45.

251. Rothoerl RD, Schebesch KM, Faltermeier R, Woertgen C, Brawanski A. Lack of correlation between Xenon133 and near infrared spectroscopy/indocyanine green rCBF measurements. Neurol Res. 2003;25:528-32.

252. Buunk G, van der Hoeven JG, Meinders AE. A comparison of near-infrared spectroscopy and jugular bulb oximetry in comatose patients resuscitated from a cardiac arrest. Anaesthesia. 1998;53:13-9. 
253. Frisch A, Suffoletto BP, Frank R, Martin-Gill C, Menegazzi JJ. Potential utility of near-infrared spectroscopy in out-of-hospital cardiac arrest: an illustrative case series. Prehosp Emerg Care. 2012;16:564-70.

254. Ter Minassian A, Poirier N, Pierrot M, et al. Correlation between cerebral oxygen saturation measured by near-infrared spectroscopy and jugular oxygen saturation in patients with severe closed head injury. Anesthesiology. 1999;91:985-90.

255. Weerakkody RA, Czosnyka M, Zweifel C, et al. Near infrared spectroscopy as possible non-invasive monitor of slow vasogenic ICP waves. Acta Neurochir Suppl. 2012;114:181-5.

256. Diedler J, Zweifel C, Budohoski KP, et al. The limitations of nearinfrared spectroscopy to assess cerebrovascular reactivity: the role of slow frequency oscillations. Anesth Analg. 2011;113:849-57.

257. Bonoczk P, Panczel G, Nagy Z. Vinpocetine increases cerebral blood flow and oxygenation in stroke patients: a near infrared spectroscopy and transcranial Doppler study. Eur J Ultrasound. 2002;15:85-91.

258. Aries MJ, Coumou AD, Elting JW, van der Harst JJ, Kremer BP, Vroomen PC. Near infrared spectroscopy for the detection of desaturations in vulnerable ischemic brain tissue: a pilot study at the stroke unit bedside. Stroke. 2012;43:1134-6.

259. Terborg C, Bramer S, Harscher S, Simon M, Witte OW. Bedside assessment of cerebral perfusion reductions in patients with acute ischaemic stroke by near-infrared spectroscopy and indocyanine green. J Neurol Neurosurg Psychiatry. 2004;75:38-42.

260. Terborg C, Groschel K, Petrovitch A, et al. Noninvasive assessment of cerebral perfusion and oxygenation in acute ischemic stroke by near-infrared spectroscopy. Eur Neurol. 2009;62:338-43.

261. Mutoh T, Ishikawa T, Suzuki A, Yasui N. Continuous cardiac output and near-infrared spectroscopy monitoring to assist in management of symptomatic cerebral vasospasm after subarachnoid hemorrhage. Neurocrit Care. 2010;13:331-8.

262. Yokose N, Sakatani K, Murata Y, et al. Bedside monitoring of cerebral blood oxygenation and hemodynamics after aneurysmal subarachnoid hemorrhage by quantitative timeresolved near-infrared spectroscopy. World Neurosurg. 2010; 73:508-13.

263. Hargroves D, Tallis R, Pomeroy V, Bhalla A. The influence of positioning upon cerebral oxygenation after acute stroke: a pilot study. Age Ageing. 2008;37:581-5.

264. Damian MS, Schlosser R. Bilateral near infrared spectroscopy in space-occupying middle cerebral artery stroke. Neurocrit Care. 2007;6:165-73.

265. Gopinath SP, Robertson CS, Contant CF, Narayan RK, Grossman RG, Chance B. Early detection of delayed traumatic intracranial hematomas using near-infrared spectroscopy. J Neurosurg. 1995;83:438-44.

266. Gopinath SP, Robertson CS, Grossman RG, Chance B. Nearinfrared spectroscopic localization of intracranial hematomas. J Neurosurg. 1993;79:43-7.

267. Wouters PF, Gehring H, Meyfroidt G, et al. Accuracy of pulse oximeters: the European multi-center trial. Anesth Analg. 2002;94:S13-6.

268. Barker SJ, Tremper KK. Pulse oximetry: applications and limitations. Int Anesthesiol Clin. 1987;25:155-75.

269. Jubran A, Tobin MJ. Reliability of pulse oximetry in titrating supplemental oxygen therapy in ventilator-dependent patients. Chest. 1990;97:1420-5.

270. Van de Louw A, Cracco C, Cerf C, et al. Accuracy of pulse oximetry in the intensive care unit. Intensive Care Med. 2001;27:1606-13.

271. Sulter G, Elting JW, Stewart R, den Arend A, De Keyser J. Continuous pulse oximetry in acute hemiparetic stroke. J Neurol Sci. 2000;179:65-9.
272. Diringer MN, Aiyagari V, Zazulia AR, Videen TO, Powers WJ. Effect of hyperoxia on cerebral metabolic rate for oxygen measured using positron emission tomography in patients with acute severe head injury. J Neurosurg. 2007;106:526-9.

273. Koutsoukou A, Perraki H, Raftopoulou A, et al. Respiratory mechanics in brain-damaged patients. Intensive Care Med. 2006;32:1947-54.

274. Bein T, Kuhr LP, Bele S, Ploner F, Keyl C, Taeger K. Lung recruitment maneuver in patients with cerebral injury: effects on intracranial pressure and cerebral metabolism. Intensive Care Med. 2002;28:554-8.

275. Nemer SN, Caldeira JB, Azeredo LM, et al. Alveolar recruitment maneuver in patients with subarachnoid hemorrhage and acute respiratory distress syndrome: a comparison of 2 approaches. J Crit Care. 2011;26:22-7.

276. Nekludov M, Bellander BM, Mure M. Oxygenation and cerebral perfusion pressure improved in the prone position. Acta Anaesthesiol Scand. 2006;50:932-6.

277. Davis DP, Dunford JV, Poste JC, et al. The impact of hypoxia and hyperventilation on outcome after paramedic rapid sequence intubation of severely head-injured patients. The Journal of trauma 2004;57:1-8; discussion 10 .

278. Davis DP, Meade W, Sise MJ, et al. Both hypoxemia and extreme hyperoxemia may be detrimental in patients with severe traumatic brain injury. J Neurotrauma. 2009;26:2217-23.

279. Pfenninger EG, Lindner KH. Arterial blood gases in patients with acute head injury at the accident site and upon hospital admission. Acta Anaesthesiol Scand. 1991;35:148-52.

280. Anderson CT, Breen PH. Carbon dioxide kinetics and capnography during critical care. Crit Care. 2000;4:207-15.

281. Curley G, Kavanagh BP, Laffey JG. Hypocapnia and the injured brain: more harm than benefit. Crit Care Med. 2010;38:1348-59.

282. Severinghaus JW. The invention and development of blood gas analysis apparatus. Anesthesiology. 2002;97:253-6.

283. Thompson JE, Jaffe MB. Capnographic waveforms in the mechanically ventilated patient. Respir Care. 2005;50:100-8 discussion 8-9.

284. Knapp S, Kofler J, Stoiser B, et al. The assessment of four different methods to verify tracheal tube placement in the critical care setting. Anesth Analg. 1999;88:766-70.

285. Ausina A, Baguena M, Nadal M, et al. Cerebral hemodynamic changes during sustained hypocapnia in severe head injury: can hyperventilation cause cerebral ischemia? Acta Neurochir Suppl. 1998;71:1-4.

286. Cold GE. Does acute hyperventilation provoke cerebral oligaemia in comatose patients after acute head injury? Acta Neurochir (Wien). 1989;96:100-6.

287. Cruz J. An additional therapeutic effect of adequate hyperventilation in severe acute brain trauma: normalization of cerebral glucose uptake. J Neurosurg. 1995;82:379-85.

288. Dexter F. Research synthesis of controlled studies evaluating the effect of hypocapnia and airway protection on cerebral outcome. J Neurosurg Anesthesiol. 1997;9:217-22.

289. Diringer MN, Videen TO, Yundt K, et al. Regional cerebrovascular and metabolic effects of hyperventilation after severe traumatic brain injury. J Neurosurg. 2002;96:103-8.

290. Diringer MN, Yundt K, Videen TO, et al. No reduction in cerebral metabolism as a result of early moderate hyperventilation following severe traumatic brain injury. J Neurosurg. 2000;92:7-13.

291. Haubrich C, Steiner L, Kim DJ, et al. How does moderate hypocapnia affect cerebral autoregulation in response to changes in perfusion pressure in TBI patients? Acta Neurochir Suppl. 2012;114:153-6.

292. Unterberg AW, Kiening KL, Hartl R, Bardt T, Sarrafzadeh AS, Lanksch WR. Multimodal monitoring in patients with head 
injury: evaluation of the effects of treatment on cerebral oxygenation. The Journal of trauma. 1997;42:S32-7.

293. Davis DP, Dunford JV, Ochs M, Park K, Hoyt DB. The use of quantitative end-tidal capnometry to avoid inadvertent severe hyperventilation in patients with head injury after paramedic rapid sequence intubation. J Trauma. 2004;56:808-14.

294. Dumont TM, Visioni AJ, Rughani AI, Tranmer BI, Crookes B. Inappropriate prehospital ventilation in severe traumatic brain injury increases in-hospital mortality. J Neurotrauma. 2010;27: 1233-41.

295. Muizelaar JP, Marmarou A, Ward JD, et al. Adverse effects of prolonged hyperventilation in patients with severe head injury: a randomized clinical trial. J Neurosurg. 1991;75:731-9.

296. Solaiman O, Singh JM. Hypocapnia in aneurysmal subarachnoid hemorrhage: incidence and association with poor clinical outcomes. J Neurosurg Anesthesiol. 2013;25:254-61. 